2. To: (Receiving Organization)

Distribution

5. Proj./Prog./Dept./Div.:

LES/HTS/Geophysics

8. Originator Remarks:

WHC-SD-EN-TI-261, Spectral Gamma-ray Logging for the

100-N Area; Hanford, Washington, Rev 0

11. Receiver Remarks:

11A. Design Baseline Document?

[] Yes
3. From: (originating Organization) Geophysics Group

6. Design Authority/ Design Agent/Cog. Engr.:

$N / A$
Yes $X]$ No

4. Related EDT No.:

N/A

7. Purchase Order No.:

N/A

9. Equip./Component No.: N/A

10. System/Bldg./Facility: N/A

12. Major Assm. Dwg. No.: $N / A$

13. Permit/Permit Application Mo.: N/A

14. Required Response Date: $N / A$

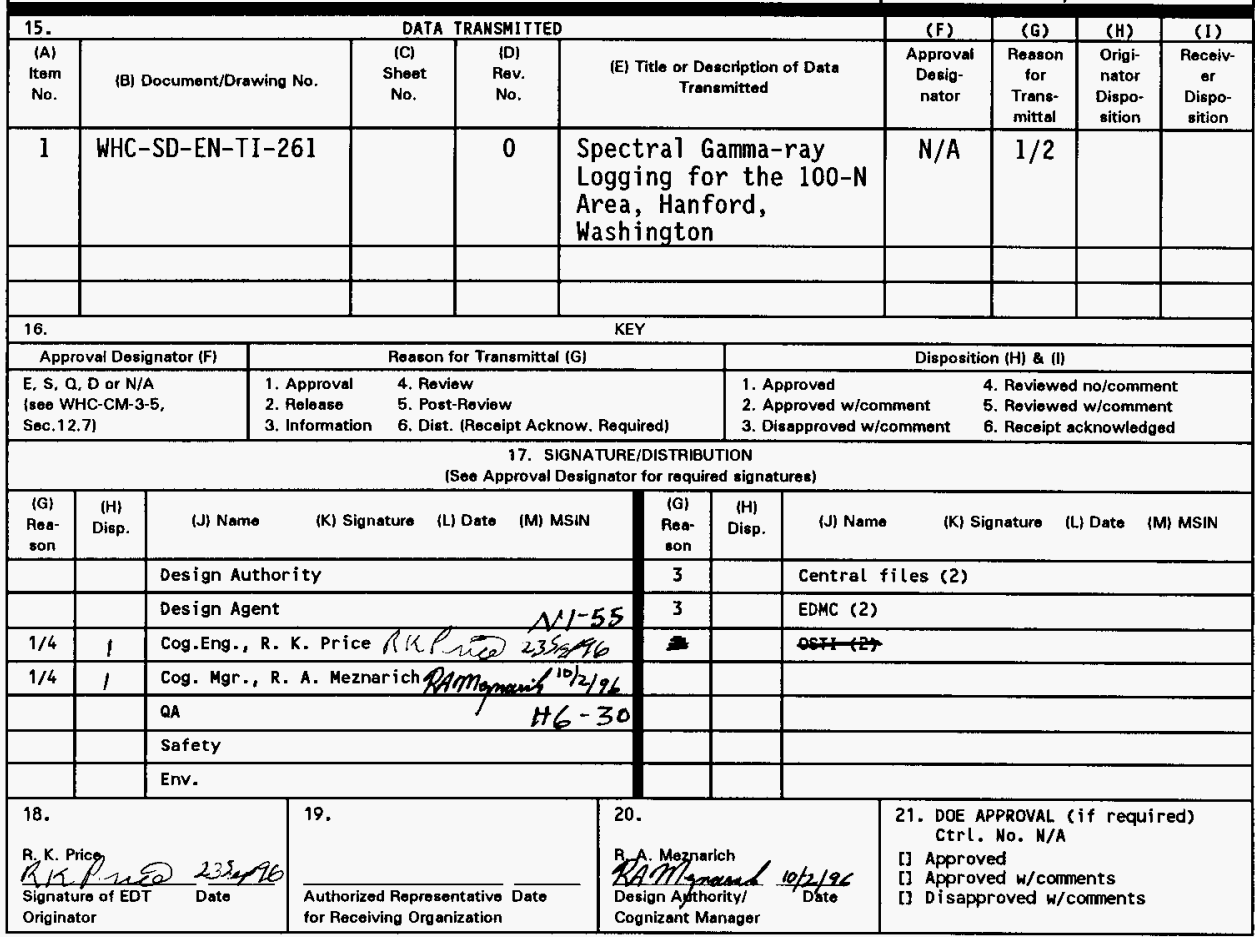

BD-7400-172-2 (05/96) GEF097 


\title{
Spectral Gamma-ray Logging for the 100-N Area; Hanford, Washington
}

\author{
G. J. Szwartz \\ Westinghouse Hanford Company, Richland, WA 99352 \\ U.S. Department of Energy Contract DE-AC06-87RL10930 \\ EDT/ECN: $610772 \quad$ UC: 630 \\ Org Code: 8H100 Charge Code: R4V11 \\ B\&R Code: EW3120100 Total Pages: 46
}

Key Words: Geophysics, Gamma-ray, RLS

Abstract: The objective of this effort was to delineate the vertical distribution and concentration of anthropogenic radionuclides in the subsurface surrounding nine boreholes in the 100-N Area available for geophysical logging with the Radionuclide Logging System (RLS). Cesium was defined in eight boreholes, and the ninth hole was found to not contain any such radionuclides.

TRADEMARK DISCLAIMER. Reference herein to any specific commercial product, process, or service by trade name, tradenark, manufacturer, or otherwise, does not necessarily constitute or imply its endorsement, recommendation, or favoring by the United States Government or any agency thereof or its contractors or subcontractors.

Printed in the United States of America. To obtain copies of this document, contact: WHC/8CS Document Control Services, P.0. Box 1970, Mailstop H6-08, Richland WA 99352, Phone (509) 372-2420; Fax (509) 376.4989.
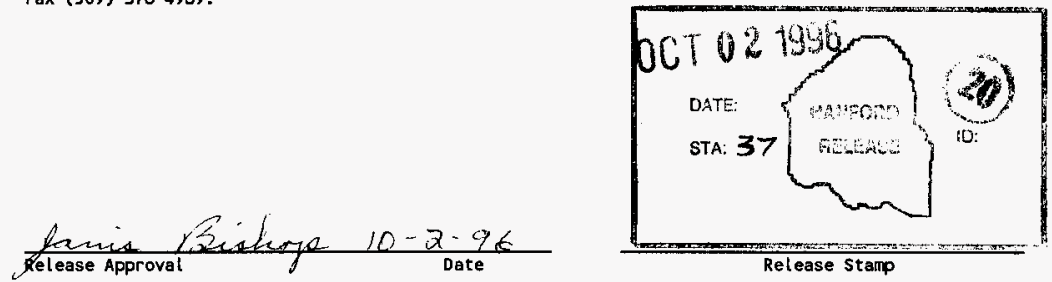

Approved for Public Release 
WHC-SD-EN-TI-261, Rev. 0

\section{CONTENTS}

1.0 INTRODUCTION $\ldots \ldots \ldots \ldots \ldots \ldots \ldots \ldots \ldots \ldots \ldots \ldots \ldots \ldots \ldots \ldots \ldots$

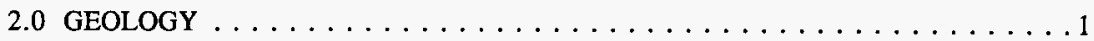

3.0 SITE DESCRIPTION $\ldots \ldots \ldots \ldots \ldots \ldots \ldots \ldots \ldots \ldots \ldots \ldots \ldots \ldots \ldots \ldots \ldots \ldots$

4.0 PREVIOUS RLS SURVEYS IN THE AREA $\ldots \ldots \ldots \ldots \ldots \ldots \ldots$

5.0 THE SURVEY DATA $\ldots \ldots \ldots \ldots \ldots \ldots \ldots \ldots \ldots \ldots \ldots \ldots \ldots \ldots \ldots$

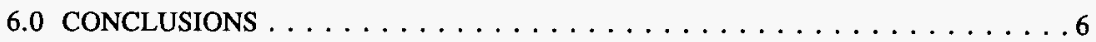

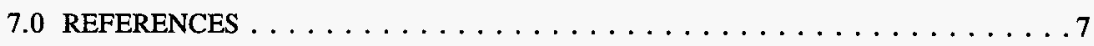

FIGURE

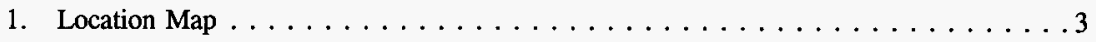

\section{TABLES}

1. $100-\mathrm{N}$ Area Borehole Logging History $\ldots \ldots \ldots \ldots \ldots \ldots \ldots \ldots \ldots \ldots \ldots \ldots$

2. Summary of Maximum Radionuclide Depths From RLS Log

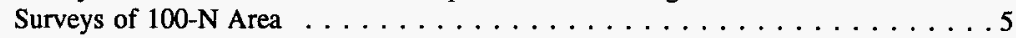

3. Summary of Detected Radionuclide Depth Ranges and Concentrations From RLS Log Surveys of $100-N$ Area $\ldots \ldots \ldots \ldots \ldots \ldots \ldots \ldots \ldots \ldots \ldots$

\section{APPENDICES}

A RLS Survey Data and Spectral Gamma Plots $\ldots \ldots \ldots \ldots \ldots \ldots$ A-1

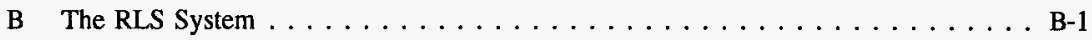


WHC-SD-EN-TI-261, Rev. 0

\section{SPECTRAL GAMMA-RAY LOGGING FOR THE 100-N AREA; HANFORD, WASHINGTON}

\subsection{INTRODUCTION}

The purpose of the project was to collect and analyze gamma-ray radiation detected in the nine 100-N Area boreholes listed in Table 1. The interpreted Radionuclide Logging System (RLS) data detailed in this report provides a basis for subsurface contamination characterization. Of the nine boreholes logged, eight were identified with the radioisotope cobalt in them with the majority of it in the 50- to 70-ft range. No other man-made isotope was identified. Only borehole $100-\mathrm{N}-56$ appears to be "clean".

The data were collected and analyzed from October 1992 through February 1993, and the data and results were transmitted to the appropriate group upon completion of the analysis. This report is intended to put the data in the public domain for future reference.

The contents of this report are limited to the description of the survey results for each borehole logged. A description and details of the RLS System and how it worked in this project and the limitations to radioelement analysis are contained in Appendix B. Readers unfamiliar with this logging system are referred to this appendix and urged to review it for pertinent information to familiarize themselves with the capabilities of the RLS and the data limitations.

Details of equipment configuration, calibration, logging procedures, casing- and water-correction factors, spectral analysis software, and data management have been excluded from this report. The details of these topics are described in the Koizumi, et. al. (1991, 1992) and Brodeur, et. al. (1991, 1992), papers cited in the References.

\subsection{GEOLOGY}

The Hanford Site lies within the Pasco Basin, a regional, structural and topographic, sediment-filled basin. The sediments for the Pasco Basin are underlain by Miocene-age basalt. The sediments overlying the basalt are from oldest to youngest as follows: MiocenePliocene Ringold Formation, post-Ringold pre-Hanford sediments, glacio-fluvial deposits of the Hanford formation, and surficial Holocene eolian and fluvial sediments.

The vadose zone beneath the 100-N Area in the northern part of the Hanford Site is comprised primarily of unconsolidated sediments of the Hanford formation. This highly permeable unit is composed of mainly cobbles, boulders, gravel, and course sand. Drilling data indicate that isolated lenses of silty sand and gravel are also present. Moisture content ranges from 1 to 3 percent in the vadose zone (Hartman 1992a, 1993). 
WHC-SD-EN-TI-261, Rev. 0

\subsection{SITE DESCRIPTION}

The 100-N Area is located adjacent to the Columbia River in the northern part of the Hanford Site (Figure 1). The 100-N Area is home to the now-retired N-Reactor and a number of waste disposal sites. Wastes discharged to the ground include radioactive cooling water and corrosive wastes. Leaking storage tanks and pipes introduced petroleum products to the ground (Hartman 1993).

Boreholes 199-N-27, $-28,-29,-39,-44$, and -70 are within $300 \mathrm{ft}$ of the $1325-\mathrm{N}$ Liquid Waste Disposal Facility (LWDF). The 1325-N LWDF received N-Reactor cooling water and fuel-storage-basin water between 1983 and 1991 (DOE 1987a). The facility comprises a concrete-covered, rectangular basin and an unlined concrete-covered extension trench. The volume of effluent discharged to the 1325-N LWDF varied with the operational status of the N-Reactor. The effluent flow was 1000 to $1600 \mathrm{gal} / \mathrm{min}$ during normal operation (Tuck $1990 \mathrm{a} / \mathrm{b}$ ). The effluent contained a suite of radionuclides, many of which were present at low activities or have short half-lives. The highest activities of radionuclides included ${ }^{90} \mathrm{Sr},{ }^{60} \mathrm{Co},{ }^{137} \mathrm{Cs}$, and ${ }^{3} \mathrm{H}$. Cobalt and cesium emit gamma rays during beta decay. Strontium and tritium decay by beta particle emissions only, but the results of the highenergy beta particles emitted by strontium can be detected by the RLS (see Appendix B). The RLS cannot delineate the energy from the strontium beta decay, but it is detectable as unresolved higher levels of gamma-ray radiation.

Minor amounts of non-radioactive dangerous wastes were also present in the waste water stream, including hydrazine and ammonia. The presence of these dangerous constituents caused the 1325-N LWDF to be classified as a RCRA disposal unit.

Borehole 199-N-56 is in close proximity to the 1301-N LWDF. The 1301-N LWDF received N-Reactor cooling water and fuel-storage-basin water between 1962 and 1985 (DOE 1987b). The facility comprises a rectangular basin connected to a zig-zagging trench with concrete sides and cover, and with an open bottom. The effluent contained radionuclides and minor amounts of dangerous waste. Composition of this effluent is assumed to be similar to that discharged to the 1325-N LWDF described above. The 1301-N is a RCRA facility.

Boreholes 199-N-75 and -76 were drilled between the river and the 1301-N LWDF outside the boundary of the 100-N Area. Well 199-N-75 was logged during the 100-NR-2 Operable Unit studies. 
Figure 1. Location Map.

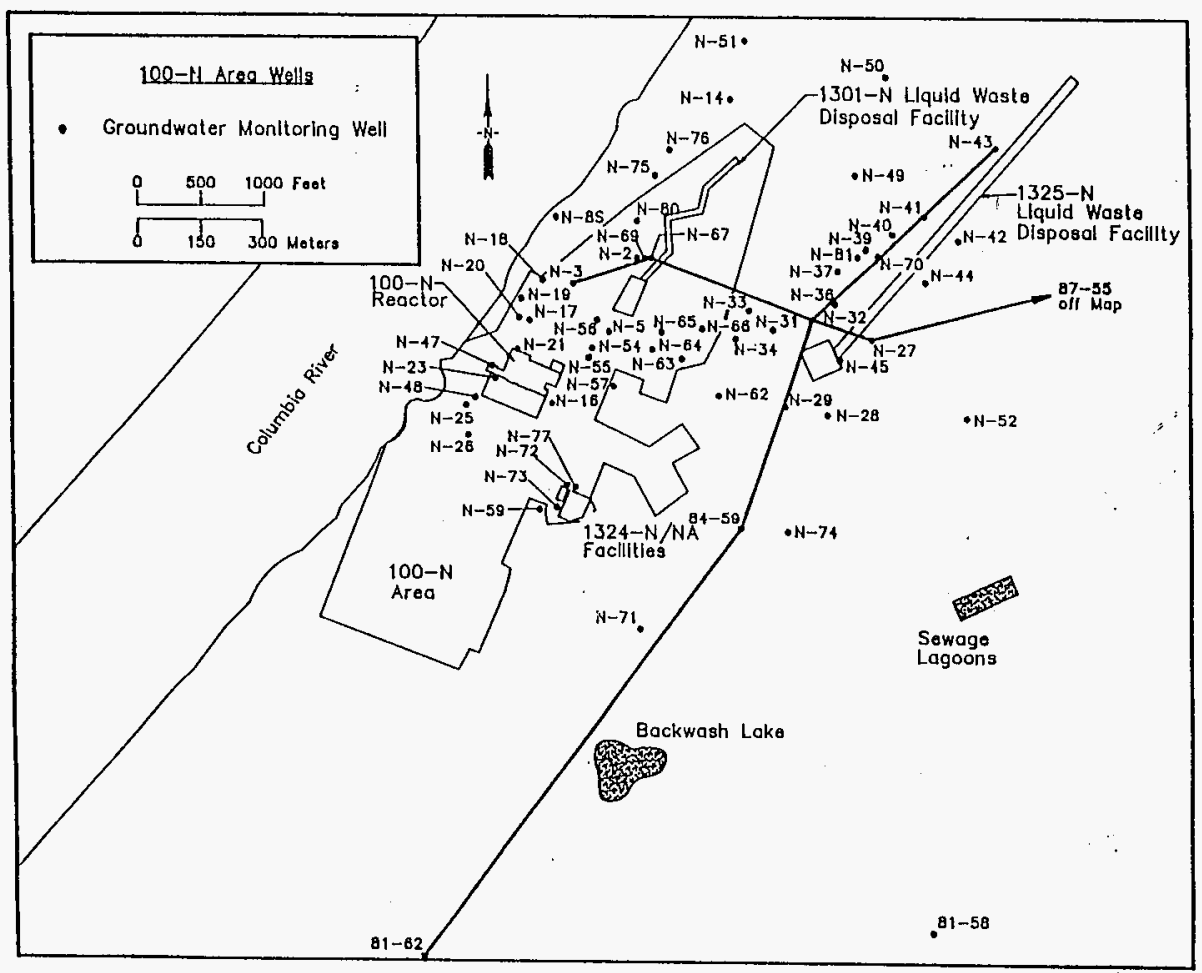




\subsection{PREVIOUS RLS SURVEYS IN THE 100-N AREA}

Many wells have been logged in the $100 \mathrm{~N}$-Area. Of the wells detailed in this report, all but one had been logged prior to 1993. The date and results of the previous surveys of each borehole are presented in Table 1.

Table 1. $100 \mathrm{~N}$-Area Borehole Logging History.

\begin{tabular}{||c|c|c|c||}
\hline Borehole & Log date & Logbase & Category \\
\hline \hline $199-\mathrm{N}-27$ & $2 / 23 / 84$ & $69^{\prime}$ & contamination \\
\hline $199-\mathrm{N}-28$ & $2 / 23 / 84$ & $84^{\prime}$ & contamination \\
\hline $199-\mathrm{N}-29$ & $2 / 28 / 84$ & $85^{\prime}$ & contamination \\
\hline $199-\mathrm{N}-39$ & $5 / 02 / 84$ & $78^{\prime}$ & natural \\
\hline $199-\mathrm{N}-44$ & $5 / 04 / 84$ & $82^{\prime}$ & natural \\
\hline $199-\mathrm{N}-56$ & $6 / 22 / 87$ & $73^{\prime}$ & possible contamination \\
\hline $199-\mathrm{N}-70$ & $5 / 17 / 88$ & $103^{\prime}$ & possible Contamination \\
\hline $199-\mathrm{N}-75$ & $4 / 29 / 92$ & $68^{\prime}$ & contamination \\
\hline $199-\mathrm{N}-76$ & $4 / 28 / 92$ & $82^{\prime}$ & contamination \\
\hline
\end{tabular}

\subsection{THE SURVEY DATA}

Appendix A, made up of individual logging summary reports for each well, contains the plotted RLS data and results. Each cover page entitled "RLS Spectral Gamma-Ray Borehole Survey Log Header" summarizes the borehole and survey information. Table 2, below, also summarizes the data. Plots of the total gamma-ray counts per second (Total Gamma) along with the calculated man-made isotope concentration data are presented on the page following the log header.

The plots of radionuclide-activity response versus depth are shown in Appendix A, with notes and a summary. On the plots in this appendix, a uniform depth scale of 20 feet per inch, and a radionuclide-concentration scale of $40 \mathrm{pCi} / \mathrm{g}$ per inch are used. The experimental uncertainties in the computed radionuclide activities are not presented on the data plots at this time. The Total Gamma is the count rate for all gamma rays detected by 
the RLS detector, with no discrimination of gamma-ray energy. The Total Gamma is equivalent to the gross gamma-ray log commonly used in the past at Hanford. The remaining plot tracks contain the results of the spectral gamma-ray analysis. The natural radionuclide gamma-ray activity, that of potassium, uranium and thorium, is discerned through the normal spectral analysis and is plotted separately on the page following the concentrations of man-made elements.

Table 2. Summary of Maximum Radionuclide Depths from RLS Log Surveys of 100 N Area.

\begin{tabular}{||c|c|c|c||}
\hline $\begin{array}{c}\text { Borehole } \\
\text { ID }\end{array}$ & $\begin{array}{c}\text { Survey } \\
\text { Date }^{1}\end{array}$ & $\begin{array}{c}\text { Survey } \\
\text { Depth }^{2}\end{array}$ & $\begin{array}{c}\text { Cobalt-60 } \\
\text { Depth }^{3}\end{array}$ \\
\hline $199-\mathrm{N}-27$ & $11 / 18 / 92$ & $66^{\prime}$ & $63^{\prime}$ \\
\hline $199-\mathrm{N}-28$ & $11 / 03 / 92$ & $80^{\prime}$ & $80^{\prime 4}$ \\
\hline $199-\mathrm{N}-29$ & $11 / 11 / 92$ & $82^{\prime}$ & $82^{\prime 4}$ \\
\hline $199-\mathrm{N}-39$ & $12 / 16 / 92$ & $61^{\prime}$ & $61^{\prime 4}$ \\
\hline $199-\mathrm{N}-44$ & $12 / 15 / 92$ & $69^{\prime}$ & $69^{\prime 4}$ \\
\hline $199-\mathrm{N}-56$ & $10 / 14 / 92$ & $70^{\prime}$ & - \\
\hline $199-\mathrm{N}-70$ & $12 / 02 / 92$ & $97^{\prime}$ & $97^{\prime 4}$ \\
\hline $199-\mathrm{N}-75$ & $05 / 01 / 92$ & $86^{\prime}$ & $85^{\prime}$ \\
\hline $199-\mathrm{N}-76$ & $12 / 03 / 92$ & $78^{\prime}$ & $77^{\prime}$ \\
\hline
\end{tabular}

${ }^{1}$ Date survey was completed

${ }^{2}$ Maximum survey depth

${ }^{3}$ Maximum depth where radionuclide was identified

${ }^{4}$ Maximum depth of borehole survey

Long-count, stationary measurements of at least 300 seconds were recorded at some depth points (stations) (seen as short bars in the data plots) in all holes to verify the data acquired at the 80-seconds-per-half- $\mathrm{ft}$ survey. Both the long and 80-second measurements were acquired at essentially some given common depth. The extended acquisition time did not identify additional radionuclides in any of these wells.

The decay activity for the natural radionuclides, potassium, uranium, and thorium, have been computed by the data reduction program and are presented on the page following the plots of the other data. 
WHC-SD-EN-TI-261, Rev. 0

\subsection{CONCLUSIONS}

No man-made radionuclides were detected with the RLS in the subsurface for well 199-N-56. All other wells detailed in this report had some level of cobalt detected. The distribution and activity of cobalt in these wells is detailed in Table 3, below.

Table 3. Summary of Detected Radionuclide Depth Ranges and Concentrations from RLS Log Surveys of 100-N Area.

\begin{tabular}{|c|c|c|c|c|c|}
\hline $\begin{array}{l}\text { Borehole } \\
\text { ID }\end{array}$ & $\begin{array}{l}\text { Radionuclide } \\
\text { Detected }^{1}\end{array}$ & $\begin{array}{l}\text { Range(s) } \\
\text { Detected }\end{array}$ & $\begin{array}{c}\text { Depth of } \\
\text { Maximum Activ. }{ }^{2}\end{array}$ & $\begin{array}{l}\text { Gross Gamma } \\
\text { Results }\end{array}$ & $\begin{array}{c}\text { Maximum } \\
\text { Indicated Activity }\end{array}$ \\
\hline $199-\mathrm{N}-27$ & Cobalt -60 & $\begin{array}{l}0-0.5^{\prime} \\
24-63^{\prime}\end{array}$ & $50^{\prime}$ & contamin & $63 \mathrm{pCi} / \mathrm{g}$ \\
\hline $199-\mathrm{N}-28$ & Cobalt -60 & $58-80^{\prime}$ & 68 & contamin & $13 \mathrm{pCi} / \mathrm{g}$ \\
\hline $199-\mathrm{N}-29$ & Cobalt -60 & $48-82^{\prime}$ & $65^{\prime}$ & contamin & $10 \mathrm{pCi} / \mathrm{g}$ \\
\hline $199-\mathrm{N}-39$ & Cobalt-60 & $45-61^{\prime}$ & $48^{\prime}$ & natural & $<1 \mathrm{pCi} / \mathrm{g}$ \\
\hline $199-\mathrm{N}-44$ & Cobalt-60 & $\begin{array}{l}0-51^{\prime 4} \\
51-69^{\prime}\end{array}$ & $66^{\prime}$ & natural & $<5 \mathrm{pCi} / \mathrm{g}$ \\
\hline $199-N-70$ & Cobalt -60 & $\begin{array}{l}1-86^{\prime 4} \\
87-96^{\prime}\end{array}$ & $89.5^{\prime}$ & possible contamin & $2.7 \mathrm{pCi} / \mathrm{g}$ \\
\hline $199-\mathrm{N}-75$ & Cobalt-60 & $52-85^{\prime}$ & - & contamin & $<1 \mathrm{pCi} / \mathrm{g}$ \\
\hline $199-N-76$ & Cobalt-60 & $\begin{array}{l}4-77^{\prime 4} \\
52-62\end{array}$ & - & contamin & $<1, \mathrm{pCi} / \mathrm{g}$ \\
\hline
\end{tabular}

The written assessment of the radioactivity made in the RLS Borehole Survey Reports in Appendix A are found in the General Notes for each borehole.

The site geology is characterized by the presence of gravelly sand with moisture less than 4 percent by weight. Based on this characterization, it is reasonable to assume that radionuclide travel in the horizontal direction would be limited. Wells $199-\mathrm{N}-39$ and 199-N-70 are within 30 meters of each other, yet spectral analysis plots in Appendix A do not reveal obvious correlations in cobalt- 60 depth nor activity, indicating no strong horizontal movement of wastes between the two boreholes in the vadose zone.

There are numerous wells in the 100-N Area which could be studied comprehensively and simultaneously to determine the spacial relationship between detected man-made radionuclides and lithology. A geostatistical analysis of this spacial relationship could be used to develop a theoretical model of the subsurface strata and contamination. However, such studies are beyond the scope of this effort at this time. 


\subsection{REFERENCES}

Brodeur, J. R., C. J. Koizumi, W. H. Ulbricht, Jr., and R. K. Price, 1991, Calibration of a High-Resolution Passive Gamma-Ray Logging System for Nuclear Waste Assessment, WHC Speech Article Report, WHC-SA-1175-FP, Westinghouse Hanford Company, Richland, Washington.

Brodeur, J. R., C. J. Koizumi, R. K. Price, and R. D. Wilson, 1992, Gamma-Ray Logging Results for the 200 Aggregate Area Management Study, WHC-SD-EN-TI-021, Westinghouse Hanford Company, Richland, Washington.

DOE, 1987a, Preliminary Closure/ Post-Closure Plan 1325-N Liquid Waste Disposal Facility, U.S. Dept. of Energy, Richland Operations Office, Richland, Washington.

DOE, 1987b, Preliminary Closure/ Post-Closure Plan 1301-N Liquid Waste Disposal Facility, U.S. Dept. of Energy, Richland Operations Office, Richland, Washington.

Hartman, M. J., 1992a, Borehole Completion Data Package for Wells 199-N-71, 199-N-72, 199-N-73, and 199-N-74, WHC-SD-EN-DP-040, Westinghouse Hanford Company, Richland Washington.

Hartman, M. J., 1992b, Results of Ground Water Quality Assessment Monitoring at the 1301-N Liquid Waste Disposal Facility and 1324-N/NA Facilities, WHC-SD-EN-EV-030, Rev.1, Westinghouse Hanford Company, Richland, Washington.

Hartman, M. J., and K. A. Lindsey, 1993, Hydrogeology of the 100N Area, Hanford Site, Washington, WHC-SD-EN-EV-027, Westinghouse Hanford Company, Richland, Washington.

Koizumi, C. J., J. R. Brodeur, W. H. Ulbricht, Jr., and R. K. Price, 1991, Calibration of the RLS HPGe Spectral Gamma-Ray Logging System, WHC-EP-0464, Westinghouse Hanford Company, Richland, Washington.

Koizumi, C. J., R. K. Price, and R. D. Wilson, 1992, Calibration of the RLS System for 200 Aggregate Area Management Study Screening Measurements, WHC-SD-EN-TRP-001, Westinghouse Hanford Company, Richland, Washington.

Tuck, J. A, 1990a, N Reactor Effluent Stream-Specific Report, WHC-EP-0342, Addenda 3 , Westinghouse Hanford Company, Richland Washington.

Tuck, J. A., 1990b, 163N Demineralization Plant Wastewater Stream-Specific Report, WHC-EP-0342, Addendum 4, Westinghouse Hanford Company, Richland, Washington. 
WHC-SD-EN-TI-261, Rev. 0

APPENDIX A

RLS SURVEY DATA AND SPECTRAL GAMMA PLOTS 
WHC-SD-EN-TI-261, Rev. 0

This page intentionally left blank.

A-2 
Project: $100-\mathrm{N}$

$\begin{aligned} & \text { Borehole } \\ & \text { Coordinates } \\ & \text { Elevation }\end{aligned} \frac{\frac{199-\mathrm{N}-27}{7728}}{449.08} \mathrm{ft}-4103$
$\mathrm{~N}$

Borehole Environment Information

\begin{tabular}{|c|c|c|c|}
\hline Borehole fluid depth 48 (ft) from zero (0.0) depth reference of log \\
\hline \hline $\begin{array}{c}\text { Casing size } \\
\text { (in.) }\end{array}$ & $\begin{array}{c}\text { Casing thickness } \\
\text { (in.) }\end{array}$ & $\begin{array}{c}\text { Top depth } \\
\text { (ft) }\end{array}$ & $\begin{array}{c}\text { Base depth } \\
\text { (ft) }\end{array}$ \\
\hline 8 & 0.30 & 0 & 69 \\
\hline
\end{tabular}

RLS Passive Spectral Gamma Survey Information

\begin{tabular}{|c|c|c|c|c|}
\hline \multicolumn{5}{|c|}{$\begin{array}{l}\text { Logging Engineers } \frac{R . V . \text { Cram }}{\text { Log depth reference at zero }(0.0)} \frac{\text { S. E. Kos }}{\text { depth is ground level }}\end{array}$} \\
\hline Log Date & $\begin{array}{l}\text { Archive } \\
\text { file names }\end{array}$ & Log mode speed & $\begin{array}{l}\text { Depth interval } \\
\text { Top Base }\end{array}$ & $\begin{array}{l}(\mathrm{ft}) \\
\text { Incr }\end{array}$ \\
\hline \multirow[t]{2}{*}{ Nov 18,92} & $H 1 N 27 \backslash A 286$ & MSA $\quad 80 \mathrm{sec}$ RT & 66 & 0.5 \\
\hline & & Station $300 \mathrm{sec}$ & $66 \mathrm{ft}$ & \\
\hline
\end{tabular}

Calibration and Analysis Information

RLS Calibration Date: Nov. 21, 1991

Calibration Report: WHC-SD-EN-TRP-001

Analyst Names: J. P. Kiesler.

Analysis Date: Dec 01, 1992

Analysis Notes:

Radionuclides Identified: $\mathrm{Co}-60, \mathrm{Cs}-137$ at the surface only 


\section{RLS Spectral Gamma-Ray Borehole Survey}

Project: $100-\mathrm{N}$

Borehole: $199-N-27$

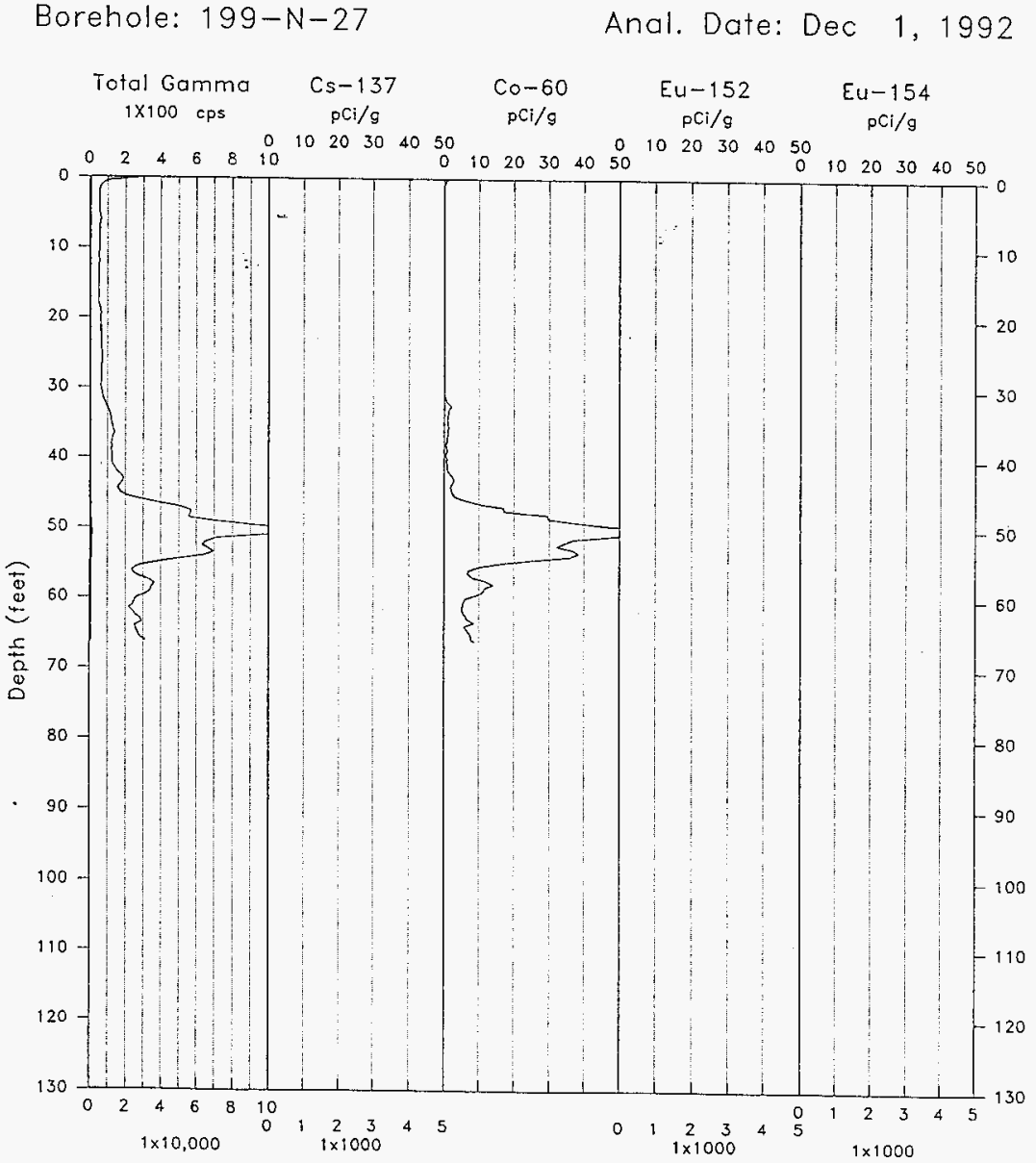

Log Date: Nov 18, 1992

Anal. Date: Dec 1, 1992 
WHC-SD-EN-TI-261, Rev. 0

\section{RLS Borehole Survey Report}

Borehole: $199-\mathrm{N}-27$

$\begin{array}{llll}\text { Casing } & \text { Depth: } 69^{\prime} & \text { Size: } 8^{\prime \prime} & \text { Thickness: } 0.30^{\prime \prime} \\ \text { Water } & \text { Depth: } 48^{\prime} & & \\ \text { Survey } & \text { Depth: } 0-66^{\prime} & \text { Date: } 11 / 18 / 92 & \\ & \text { Station } 66^{\prime} & & \end{array}$

General Notes:

Man-made Radionuclides:

Cesium (Cs-137) was detected only at the surface near the threashold of detection.

Cobalt $\left(C_{0}-60\right)$ was detected at the surface, 0 to 0.5 feet, and from 24 to 63

feet. The indicated activity was less than $1 \mathrm{pCi} / \mathrm{g}$ "at the surface and the maximum activity detected was $63 \mathrm{pCi} / \mathrm{g}$ at $50 \mathrm{feet}$.

No Europium (Eu-152) detected, template presented for uniformity of presentation only.

No Europium (Eu-154) detected, template presented for uniformity of presentation on $7 y$. 


\section{Westinghouse Hanford Company \\ RLS Spectral Gamma-Ray Borehole Survey Log Header}

Project: $100-\mathrm{N}$

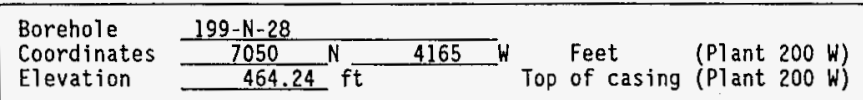

Borehole Environment Information

\begin{tabular}{|c|c|c|c|}
\hline \multicolumn{2}{|c|}{ Borehole fluid depth 63 (ft) from zero (0.0) depth reference of log } \\
\hline \hline $\begin{array}{c}\text { Casing size } \\
\text { (in.) }\end{array}$ & $\begin{array}{c}\text { Casing thickness } \\
\text { (in.) }\end{array}$ & $\begin{array}{c}\text { Top depth } \\
(\mathrm{ft})\end{array}$ & $\begin{array}{c}\text { Base depth } \\
\text { (ft) }\end{array}$ \\
\hline 8 & 0.31 & 0 & 48 \\
\hline
\end{tabular}

RLS Passive Spectral Gamma Survey Information

\begin{tabular}{|c|c|c|c|c|c|}
\hline \multicolumn{6}{|c|}{$\begin{array}{l}\text { Logging Engineers } \frac{R . V . \text { Cram }}{\text { S. E. Kos }} \\
\text { Log depth reference at zero }(0.0) \text { depth is ground level }\end{array}$} \\
\hline Log Date & $\begin{array}{c}\text { Archive } \\
\text { file names }\end{array}$ & Log mode speed & $\begin{array}{l}\text { Depth } \\
\text { Top } \\
\end{array}$ & $\begin{array}{c}\text { interva } \\
\text { Base }\end{array}$ & $\begin{array}{l}\text { (ft) } \\
\text { Incr }\end{array}$ \\
\hline \multirow[t]{2}{*}{ Nov 03,92} & $H 1 N 28 \backslash A 274$ & MSA $\quad 80 \mathrm{sec}$ RT & $\begin{array}{r}0 \\
45 \\
\end{array}$ & $\begin{array}{l}45 \\
80\end{array}$ & $\begin{array}{l}0.5 \\
0.5\end{array}$ \\
\hline & & Station $300 \mathrm{sec}$ & \multicolumn{3}{|c|}{$80 \mathrm{ft}$} \\
\hline & & & & & \\
\hline
\end{tabular}

Calibration and Analysis Information

RLS Calibration Date: Nov. 21, 1991

Calibration Report: WHC-SD-EN-TRP-001

Analyst Names: J.P. Kiesler

Analysis Date: Dec 01, 1992

Analys is Notes: No correction applied for well screen 43 to 83 feet

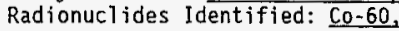




\section{RLS Spectral Gamma-Ray Borehole Survey}

Project: $100-\mathrm{N}$

Borehole: $199-N-28$

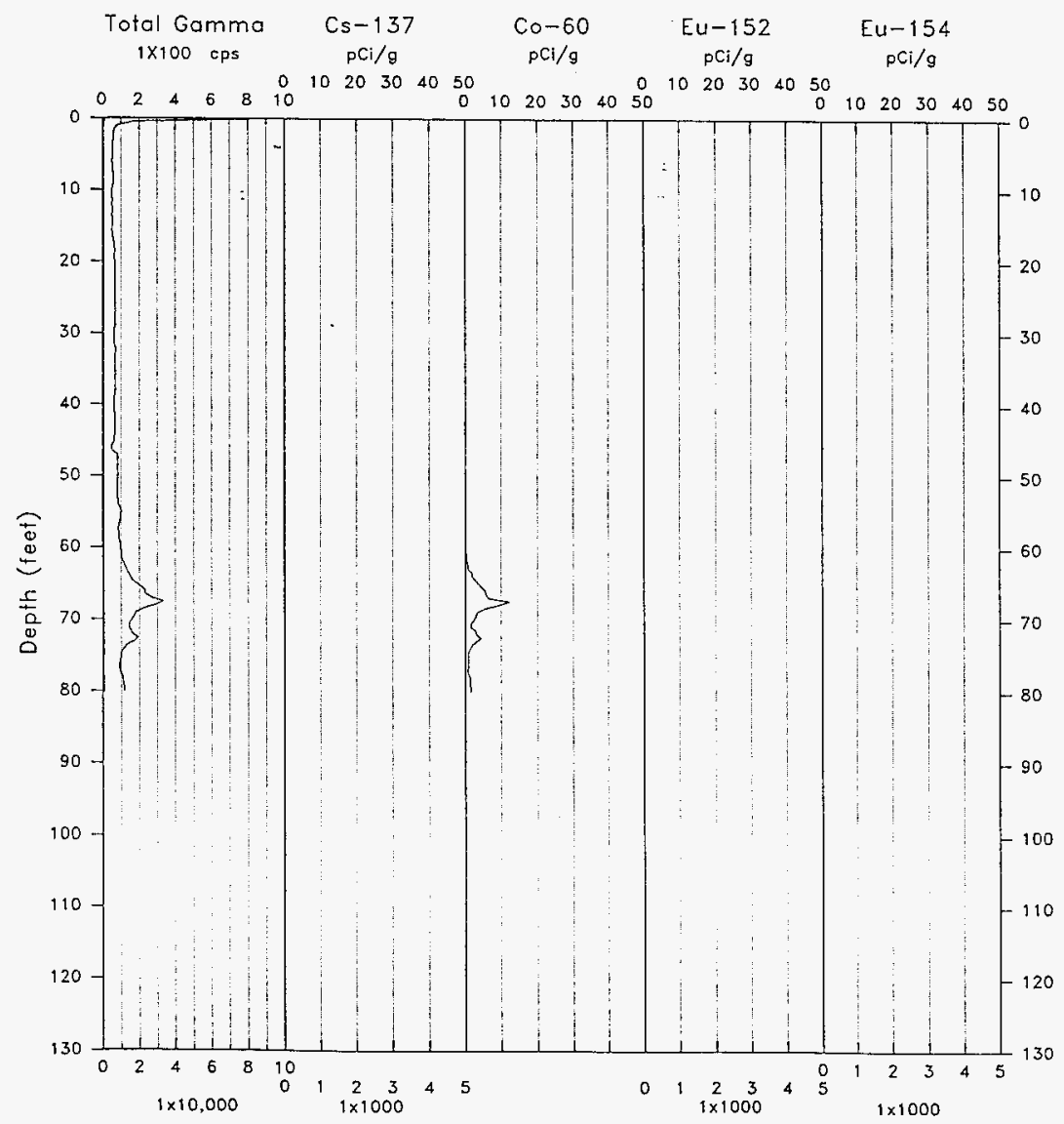

Log Date: Nov 3, 1992

Anal. Date: Dec 2. 1992 
WHC-SD-EN-TI-261, Rev. 0

RTS Borehole Survey Report

Borehole: $199-\mathrm{N}-28$

$\begin{array}{llll}\text { Casing } & \text { Depth: } 48^{\prime} & \text { Size: } 8^{\prime \prime} & \text { Thickness: } 0.31^{\prime \prime} \\ \text { Screen } & \text { Depth: } 43^{\prime}-83^{\prime} & & \\ \text { Water } & \text { Depth: } 63^{\prime} & & \\ \text { Survey } & \text { Depth: } 0-45^{\prime} & \text { Date: } 11 / 03 / 92 \\ & & 45-80^{\prime} & \end{array}$

General Notes:

No correction is availabie for the well screen and activities may be higher than indicated.

Man-made Radionuclides:

Cobalt $(\mathrm{Co}-60)$ was detected at the surface and from 58 to 80 feet. The indicated activity was less than $1 \mathrm{pCi} / \mathrm{g}$ at the surface and the maximum activity detected was $13 \mathrm{pCi} / \mathrm{g}$ at 68 feet.

No Europium (Eu-152) detected, template presented for uniformity of presentration only.

No Europium (Eu-154) detected, template presented for uniformity of presentation only.

No Cesium (Ce-137) detected, template presented for uniformity of presentation only. 
Westinghouse Hanford Company

RLS Spectral Gamma-Ray Borehole Survey Log Header

Project: $100-\mathrm{N}$

Borehole
Coordinates
Elevation $\frac{\frac{199-N-29}{6943} \mathrm{~N}}{465.25} \mathrm{ft}$ T525 Feet (Plant 100 Area)

Borehole Environment Information

\begin{tabular}{|c|c|c|c|}
\hline $\begin{array}{c}\text { Casing size } \\
\text { (in.) }\end{array}$ & $\begin{array}{c}\text { Casing thickness } \\
\text { (in.) }\end{array}$ & $\begin{array}{c}\text { Top depth } \\
\text { (ft) }\end{array}$ & $\begin{array}{c}\text { Base depth } \\
(\mathrm{ft})\end{array}$ \\
\hline 8 & 0.30 & 0 & 85 \\
\hline $\begin{array}{l}\text { telescoping } \\
\text { screen }\end{array}$ & unknown & 47.5 & 84 \\
\hline
\end{tabular}

RLS Passive Spectral Gamma Survey Information

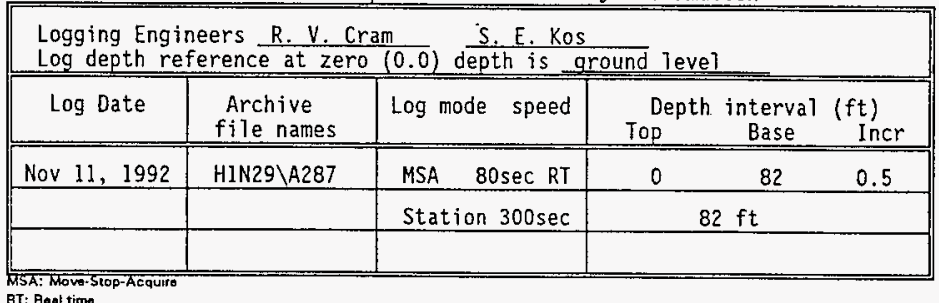

Calibration and Analysis Information

RLS Calibration Date: Nov. 21, 1991

Calibration Report: WHC-SD-EN-TRP-001

Analyst Names: J. P. Kiesler R. K. Price

Analysis Date: Feb 15, 1993

Analysis Notes: Comparison with $2 / 23 / 84$ survey indicates differences. Radionuclides Identified: $\mathrm{C}_{0}-60$ 
RLS Spectral Gamma-Ray Borehole Survey

Project: $100-\mathrm{N}$

Borehole: $199-N-29$
Log Date: Nov 19, 1992

Anal. Date: Feb 15, 1993

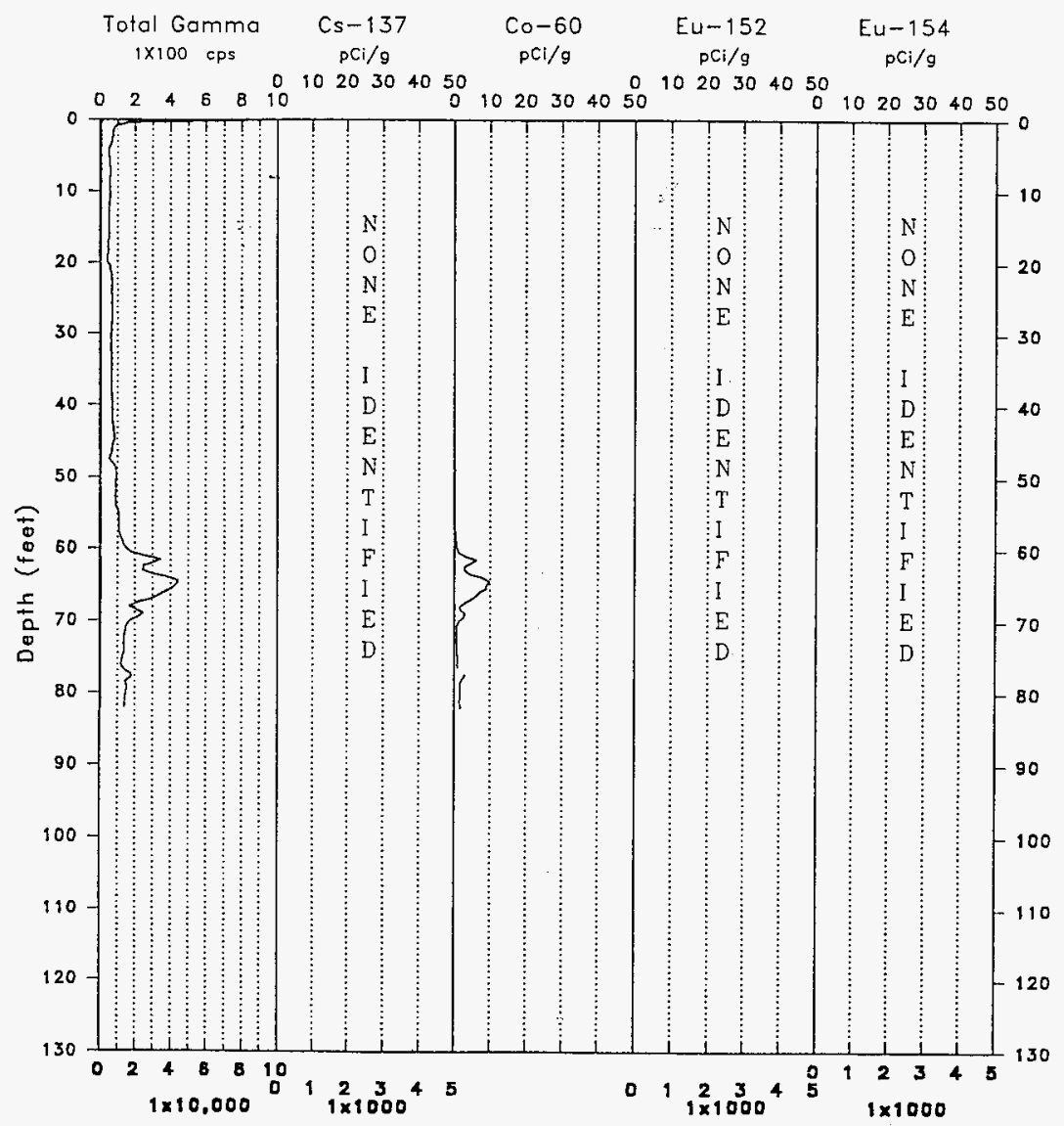


RLS Spectral Gamma-Ray Borehole Survey

Project: $\quad 100-\mathrm{N}$

Borehole : $100-N-29$
Log Date : Nov 19, 1992

Anal Dote: Feb 15, 1993

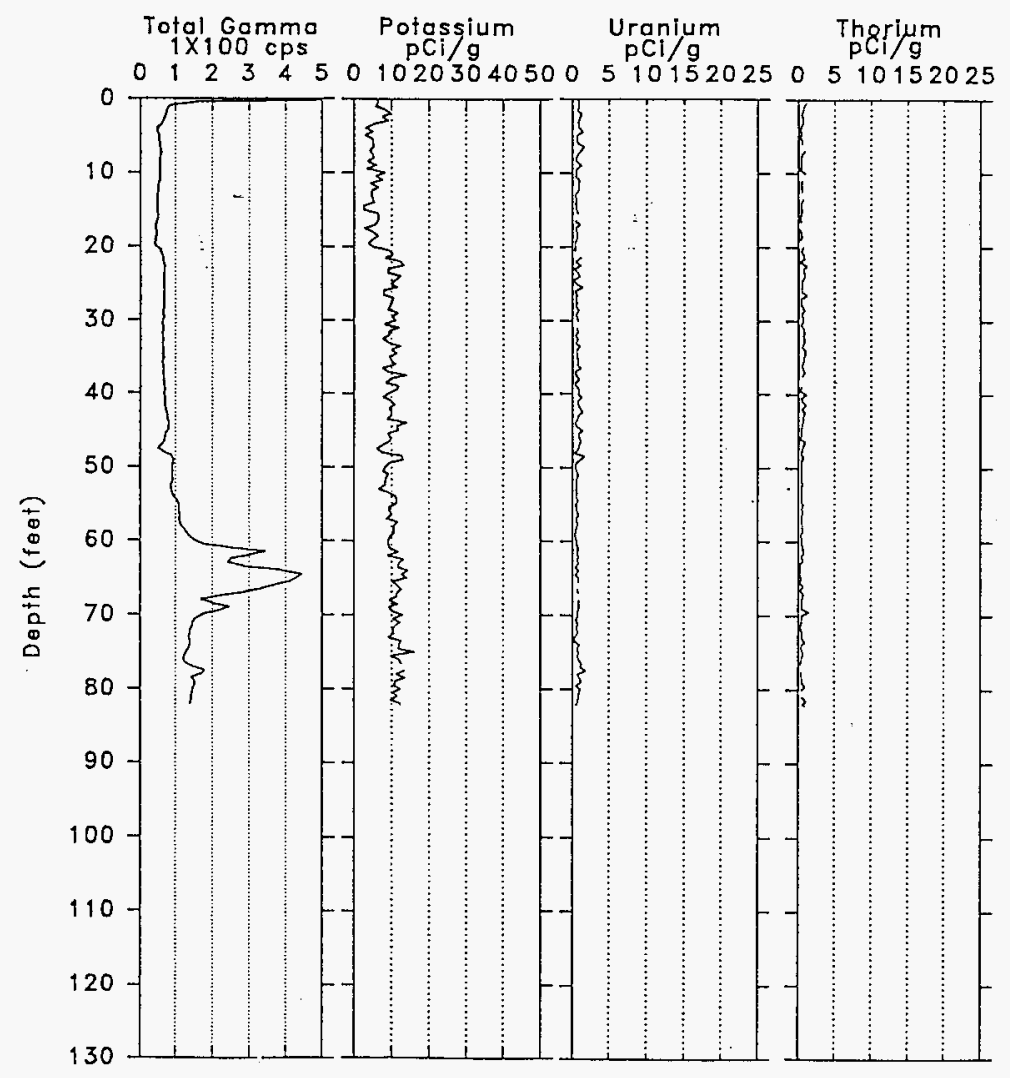


WHC-SD-EN-TI-261, Rev. 0

R1S Borehole Survey Report

Borehole: 199-N-29

$\begin{array}{llll}\text { Casing } & \text { Depth: } 85^{\prime} & \text { Size: } 8^{\prime \prime} & \text { Thickness: } 0.30^{\prime \prime} \\ \text { Screen } & \text { Depth: } 47.5 \text { to } 84^{\prime} & \text { Size: telescoping screen unknown } \\ \text { Water } & \text { Depth: } 64^{\prime} & & \\ \text { Survey } & \text { Depth: } 02^{\prime} & \text { Date: } 11 / 19 / 92 & \end{array}$

General Notes:

High activity at surface contributed to the borehole survey spectra to the depth of 1 foot. No gamma-ray photo peaks were associated with the elevated count rate. It is unclear whether the source is backscattered gamma rays or bremsstrahlung radiation induced from the high-energy beta emissions of strontium-90.

A cement grout extends from the surface to approximately 20 feet and $i$ ts effect is detected as a zone of decreased gamma activity as indicated in the total gamma plot curve. The 8 inch diameter casing extends to 49 feet and a telescoping screen extends from 47.5 to 84 feet.

No correction factor is applied for the telescoping screen thus calculated gamma activities are probably higher than those present in the formation.

This RLS survey indicates a change has occured in the subsurface conditions since the previous survey, a gross-gamma log acquired by PNL on $2 / 23 / 84$. The change is identifiable inspite of the differences in the survey specifications that include logging speed, time constant averaging, detector response characteristics, sample increment, and recording format. The 1984 survey indicated three depths of elevated gamma activity. They are located at 64, 67 and the maximum survey depth of 85 feet. The RLS survey terminated at 82 feet due to detector location within the probe. Consequently the elevated gamma activity at 85 feet was not evaluated. The RLS survey identified four depths of elevated activity. They are located at $61.5,64.5,69$ and 77.5 feet. The depths do not match identically between the two surveys but are within 3 precent of each other.

The primary depth zone at 64 feet appears to be unchanged when compared with the background interval from 30 to 40 feet. The 8.5 year time difference and the source radionuclide of cobalt-60 with a 5.3 year half live is apparentiy being replenished from some source. The depth zone at 61.5 feet is indicated on the gross gamma survey but was not resolved as a separate peak. The depth zone at 69 feet appears to have moved from 67 feet on the gross gamma. The depth zone at 77.5 feet appears to correlate with the beginnings of an elevated count at 80 feet. The indicated peak depths correlate well between the two surveys but the observed activity in the peaks are significantly different. A copy of the gross gamma survey is inciuded.

Man-made Radionuclides: Cobalt $\left(\mathrm{C}_{0}-60\right)$ was detected from 48 to 82 feet. The maximum calculated activity was less than $10 \mathrm{pCi} / \mathrm{g}$ at 65 feet. 


\section{Westinghouse Hanford Company \\ RLS Spectral Gamma-Ray Borehole Survey Log Header}

Project: $100-\mathrm{N}$

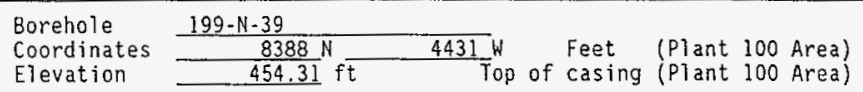

Borehole Environment Information

\begin{tabular}{|c|c|c|c|}
\hline \begin{tabular}{c} 
Borehole liquid depth none (ft) from zero (0.0) depth reference of log \\
\hline \hline $\begin{array}{c}\text { Casing size } \\
\text { (in.) }\end{array}$
\end{tabular} & $\begin{array}{c}\text { Casing thickness } \\
\text { (in.) }\end{array}$ & $\begin{array}{c}\text { Top depth } \\
\text { (ft) }\end{array}$ & $\begin{array}{c}\text { Base depth } \\
(\mathrm{ft})\end{array}$ \\
\hline 8 & 0.254 & 0 & 64.5 \\
\hline & & & \\
\hline & & & \\
\hline
\end{tabular}

RLS Passive Spectra] Gamma Survey Information

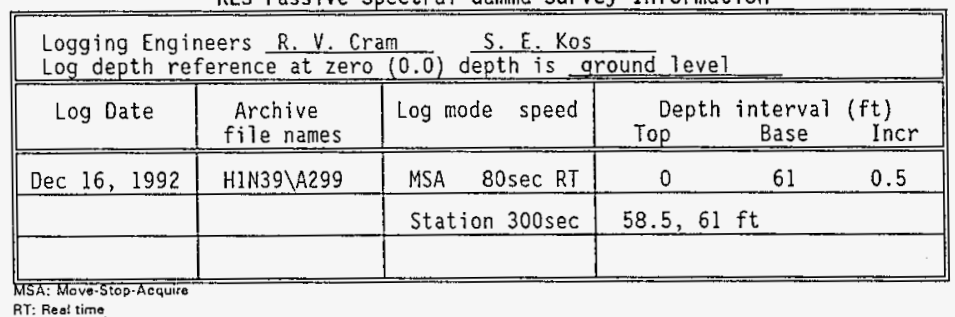

Calibration and Analysis Information

RLS Cailibration Date: Nov. 21, 1991

Calibration Report: WHC-SD-EN-TRP-0O1

Analyst Names: W. F. Nicaise

Analysis Date: Jan. 07, 1993

Anaiys is Notes:

Radionuclides identified: Co-60 


\section{RLS Spectral Gamma-Ray Borehole Survey}

Project: $\quad 100-N$

Borehole: 199-N-39
Log Date: Dec 16, 92

Anal. Date: Jan 07, 93

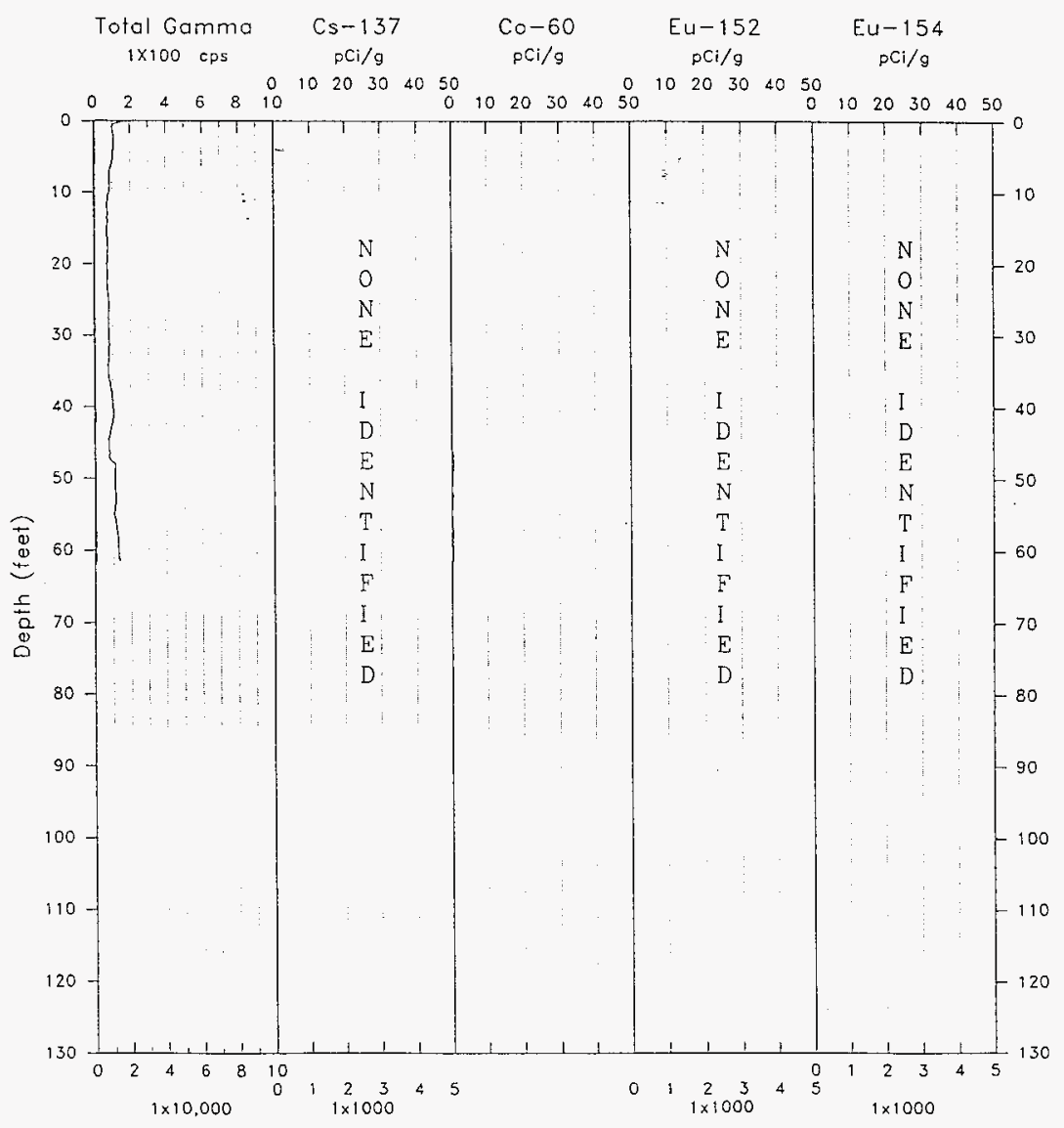

A-14 


\section{RLS Spectral Gamma-Ray Borehole Survey}

Project: $100-\mathrm{N}$

Borehole : $199-N-39$
Log Date : Dec 16, 1992

Anal Date: Jan 07, 1993

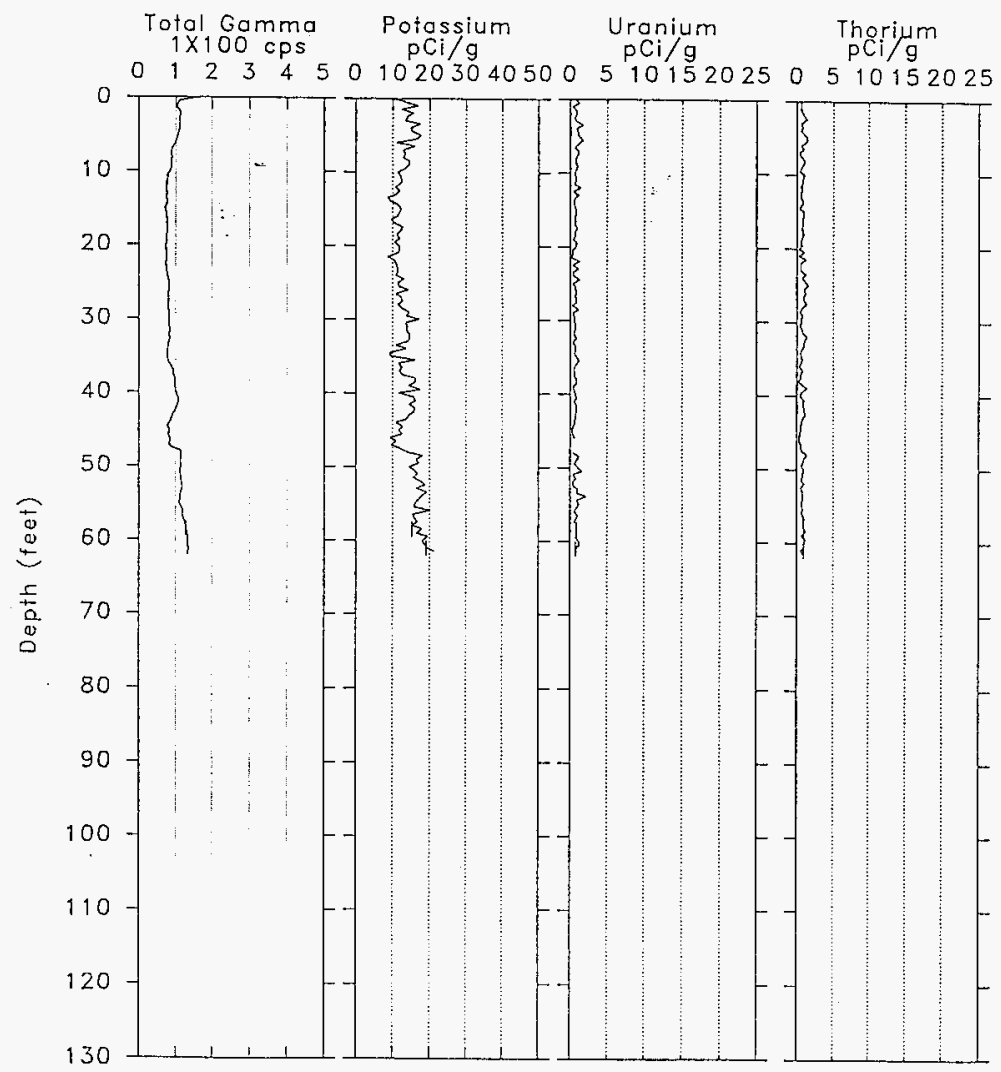


WHC-SD-EN-TI-261, Rev. 0

RLS Borehole Survey Report

Borehole: $199-\mathrm{N}-39$

$\begin{array}{llll}\text { Casing } & \text { Depth: } 64.5^{\prime} & \text { Size: } 8^{\prime \prime} & \text { Thickness: } 0.254^{\prime \prime} \\ \text { Water } & \text { Depth: none } & & \\ \text { Survey } & \text { Depth: } 0-61^{\prime} & \text { Date: } 12 / 16 / 92 & \\ & \text { Stations: } 58.5^{\prime}, 61^{\prime} & \end{array}$

General Notes:

The well was monitored at fixed positions at 0.5 -foot intervals from ground level ( $0 \mathrm{ft}$ ) to 61.5 feet, for real counting times of 80 seconds. Naturally occurring thorium and uranium are present at normal Hanford activities of less than one $\mathrm{pCi} / \mathrm{g}$. Potassium is observed at slightly elevated near the bottom of the $\log$ survey from about 50 feet to 61.5 feet. As shown on the second plot the total gamma count rate follows the potassium activity profile closely.

The first plot shows the total gamma count rate along with the activity profile for $\mathrm{C}_{0}-60$, which is described below. By comparing these results with the well-construction diagram for well $199-\mathrm{N}-39$ on page 232 of document WHCSO-ER-TI-006, Rev. 0 , it may be seen that increased readings of potassium, Co60 , and total gamma begin at a depth of about 50 feet, where the well casing ends and a telescoping screen begins, extending to the bottom of the well. This depth also denotes the interface between the Hanford and Ringold formations. An increase of Potassium activity is expected in the Ringold formation. Both of these structural effects likely elevate the calculated activity values.

Man-made Radionuclides:

Cobalt $($ Co-60) decay activity was observed from approximately 45 to 61 feet. The maximum activity, which occurred at 48 feet, is less than one $\mathrm{pCi} / \mathrm{g}$.

No Cesium (Cs-137) was observed in the well. The template is shown for uniformity of presentation only.

No Europium (Eu-154) was observed in the well. The template is shown for uniformity of presentation only.

No Europium (Eu-152) was observed in the well. The template is shown for uniformity of presentation only. 
Project: $100-\mathrm{N}$

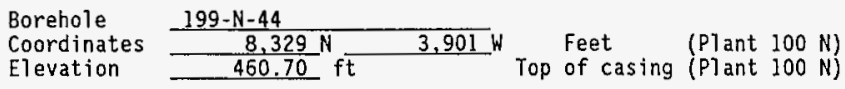

Borehole Environment Information

\begin{tabular}{|c|c|c|c|}
\hline \multicolumn{4}{|c|}{ Borehole fluid depth none $(\mathrm{ft})$ from zero $(0.0)$ depth reference of 70} \\
\hline $\begin{array}{c}\text { Casing size } \\
\text { (in.) }\end{array}$ & $\begin{array}{c}\text { Casing thickness } \\
\text { (in.) }\end{array}$ & $\begin{array}{c}\text { Top depth } \\
(\mathrm{ft})\end{array}$ & $\begin{array}{c}\text { Base depth } \\
(\mathrm{ft})\end{array}$ \\
\hline 8 & 0.28 & 0 & 82 \\
\hline & & & \\
\hline & & & \\
\hline
\end{tabular}

RLS Passive Spectral Gamma Survey Information

\begin{tabular}{|c|c|c|c|c|}
\hline \multicolumn{5}{|c|}{$\begin{array}{l}\text { Logging Engineers } \frac{R . V . C r a m}{10} \frac{\text { J.P. Kiesler }}{\text { Log depth reference at zero }(0.0)} \text { depth is ground level }\end{array}$} \\
\hline Log Date & $\begin{array}{c}\text { Archive } \\
\text { file names } \\
\end{array}$ & Log mode speed & $\begin{array}{l}\text { Depth interva } \\
\text { Top Base }\end{array}$ & $\begin{array}{l}(\mathrm{ft}) \\
\text { Incr }\end{array}$ \\
\hline \multirow[t]{2}{*}{ Dec 15, 1992} & HIN44 A298 & MSA $80 \mathrm{sec}$ RT & 69 & 0.5 \\
\hline & & Stations $300 \mathrm{sec}$ & $50 \& 69$ & \\
\hline
\end{tabular}

RT: Roal timo

Calibration and Analysis Information

RLS Calibration Date: Nov. 21, 1991

Calibration Report: WHC-SD-EN-TRP-001

Analyst Names: J.P. Kiesler R. K. Price Analysis Date: Jan 19, 1993

Analysis Notes:

Radionuclides Identified: $\mathrm{Co-50}$ 


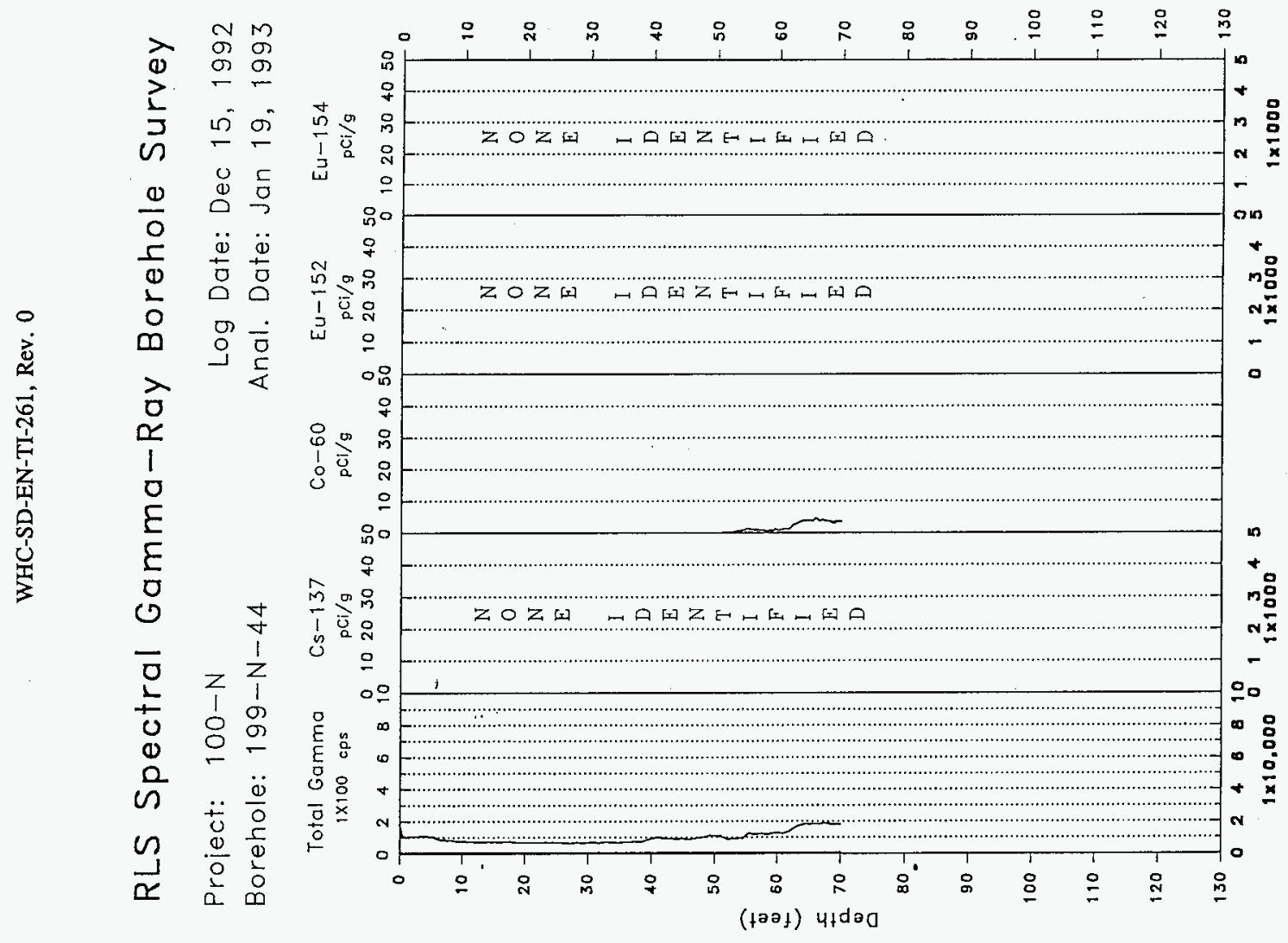




RLS Spectral Gamma-Ray Borehole Survey
Project: $100-\mathrm{N}$
Borehole: $199-\mathrm{N}-44$

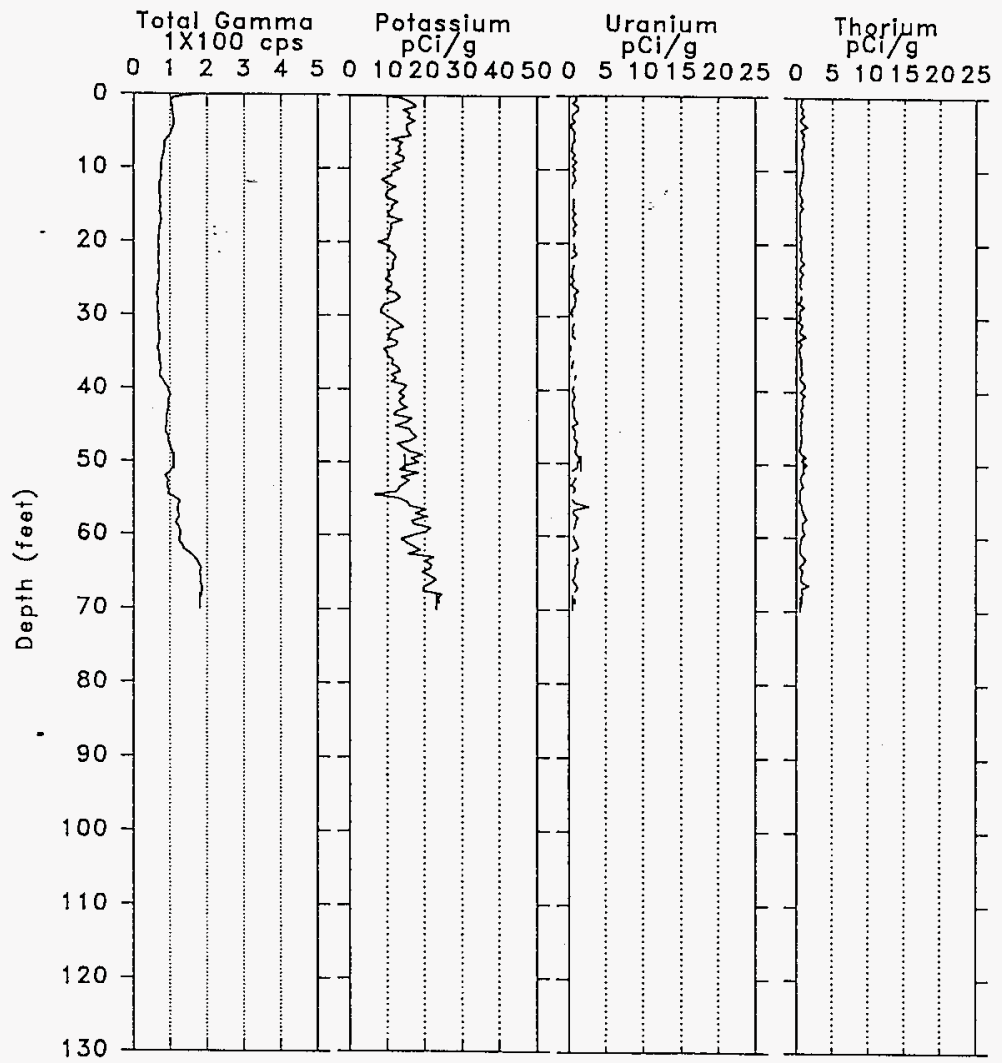


WHC-SD-EN-TI-261, Rev. 0

RLS Borehole Survey Report

Borehole: $\quad 199-\mathrm{N}-44$

$100-N$ Area

$\begin{array}{llll}\text { Casing } & \text { Depth: } 82^{\prime} & \text { Size: } 8^{\prime \prime} & \text { Thickness: } 0.28^{\prime \prime} \\ \text { Water } & \text { Depth: none } & & \\ \text { Survey } & \text { Depth: } 0-69^{\prime} & \text { Date: } 12 / 15 / 92 & \\ & \text { Stations: } 50 \& 69^{\prime} & & \end{array}$

General Notes:

The plots for potassium, thorium, and uranium show that the calculated potassium activities vary between about 7 and $25 \mathrm{pCi} / \mathrm{g}$ over the logged interval, and the thorium and uranium activities are much smaller than $5 \mathrm{pCi} / \mathrm{g}$ over the logged interval. The activity variations are within the statistical uncertainties of the measurements. The Potassium, uranium, and thorium activities are typical of background due to naturally occurring radioelements in the sediments in the area.

Man-made Radionuclides:

Cobalt-60 (Co-60) was identified in the borehole from 0 to 51 feet with the only continuous zone being 51 to the maximum depth of 69 feet. The decay activity detected was less than $5 \mathrm{pCj} / \mathrm{g}$ at 66 feet. 
Westinghouse Hanford Company

RLS Spectral Gamma-Ray Borehole Survey Log Header

Project: $100-\mathrm{N}$

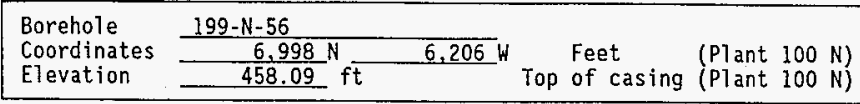

Borehole Environment Information

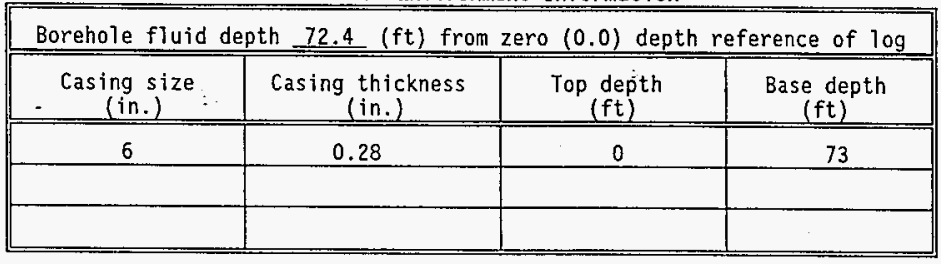

RLS Passive Spectral Gamma Survey Information

\begin{tabular}{|c|c|c|c|c|}
\hline \multicolumn{5}{|c|}{$\begin{array}{l}\text { Logging Engineers } R . V . \text { Cram } \\
\text { Log depth reference at zero }(0.0) \text { depth is ground level }\end{array}$} \\
\hline Log Date & $\begin{array}{l}\text { Archive } \\
\text { file names }\end{array}$ & Log mode speed & $\begin{array}{l}\text { Depth interva } \\
\text { Top Base }\end{array}$ & (ft) \\
\hline \multirow[t]{2}{*}{ Oct 14,1992} & $H 1 N 56 \backslash A 297$ & MSA $80 \mathrm{sec}$ RT & 70 & 0.5 \\
\hline & & Stations 300 sec & $48,50 \& 70$ & \\
\hline
\end{tabular}

Calibration and Analysis Information

RLS Calibration Date: Nov. 21, 1991

Calibration Report: WHC-SD-EN-TRP-001

Analyst Names: 3.P. Kiesler $\quad$ R. K. Price

Analys is Date: Jan 19,1993

R. $x_{\text {. Price }}$

Analysis Notes:

Radionuclides Identified: No man-made nuclides identified 
WHC-SD-EN-TI-261, Rev. 0

\begin{abstract}
RLS Spectral Gamma-Ray Borehole Survey
Project: $100-\mathrm{N}$

Borehole : $100-N-56$

Log Date : Oct 14, 1992

Anal Date: Jan 19, 1993
\end{abstract}

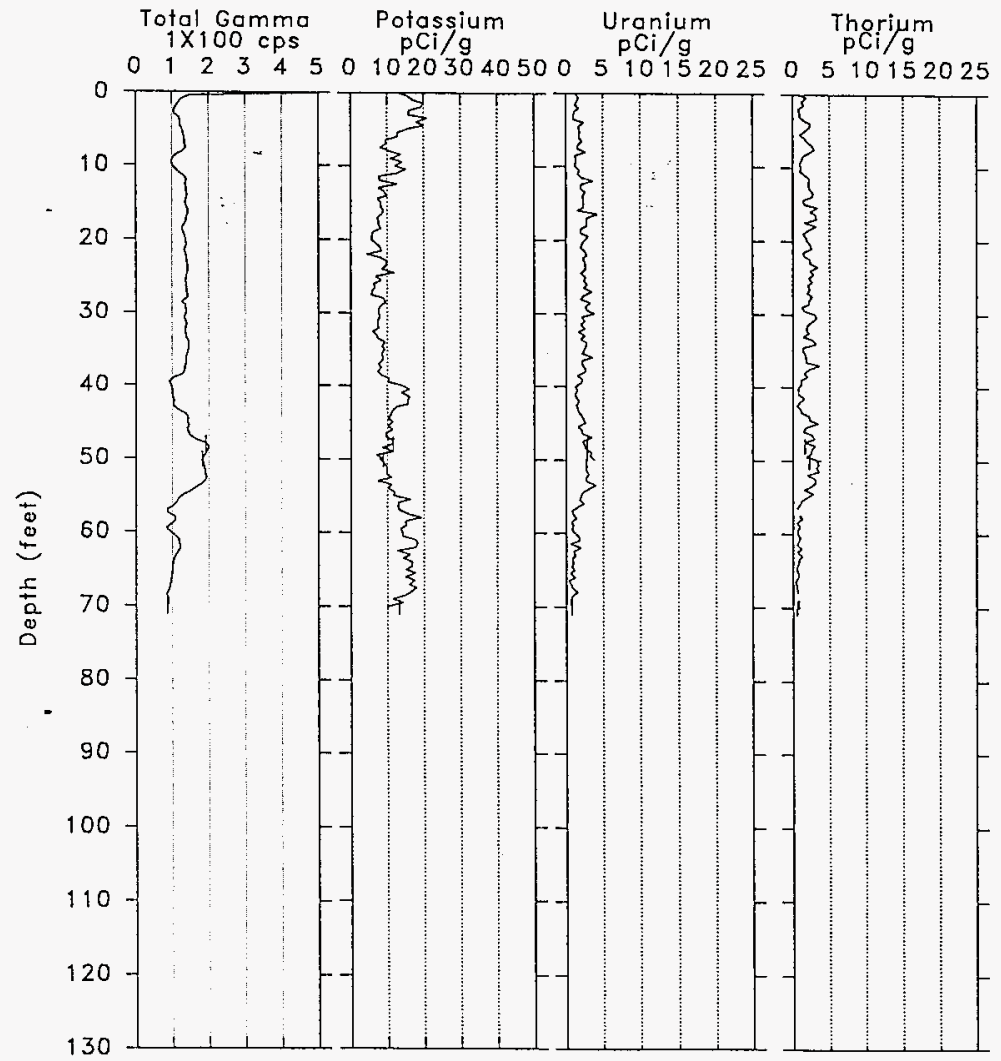




\section{WHC-SD-EN-TI-261, Rev. 0}

\section{RLS Borehole Survey Report}

Borehole: 199-N-56

$\begin{array}{llll}\text { Casing } & \text { Depth: } 73^{\prime} & \text { Size: } 6^{\prime \prime} & \text { Thickness: } 0.28^{\prime \prime} \\ \text { Water } & \text { Depth: } 72.4^{\prime} & & \\ \text { Survey } & \text { Depth: } 0-70^{\prime} & \text { Date: } 10 / 14 / 92 & \\ & \text { Stations: } 48,50 \& 70^{\prime} & \end{array}$

General Notes:

The plots for potassium, uranium and thorium show that the calculated potassium decay activities vary between about 5 and $20 \mathrm{pCi} / \mathrm{g}$ over the logged interval, and the uranium and thorium decay activities are less than $5 \mathrm{pC} i / \mathrm{g}$. The computed potassium decay activity varies inversely with the uranium and thorium activities, which is not common to the Hanford environment. The elevated uranium and thorium decay activity is believed to orginate from the bentonite sealing. material.

The total gamma activity did not exceed $200 \mathrm{cps}$ in the borehole survey with the exception of the spectrum at 0.0 feet with total activity of $580 \mathrm{cps}$, which is believed to be shine from another source.

Man-made Radionuclides:

No man-made radionuclides identified 


\section{Westinghouse Hanford Company}

RLS Spectral Gamma-Ray Borehole Survey Log Header

Project: $100-\mathrm{N}$

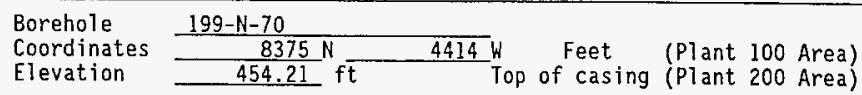

Borehole Environment Information

\begin{tabular}{|c|c|c|c|}
\hline \multicolumn{1}{|c|}{\begin{tabular}{c} 
Borehole Tiquid depth 59 \\
\hline $\begin{array}{c}\text { Casing size } \\
\text { (in.) }\end{array}$
\end{tabular}} & $\begin{array}{c}\text { Casing thickness } \\
\text { (in.) }\end{array}$ & $\begin{array}{c}\text { Top depth } \\
(\mathrm{ft})\end{array}$ & $\begin{array}{c}\text { Base depth } \\
\text { (ft) }\end{array}$ \\
\hline 6 & 0.25 & 0 & 103 \\
\hline & & & \\
\hline & & & \\
\hline
\end{tabular}

RLS Passive Spectral Gamma Survey Information

\begin{tabular}{|c|c|c|c|c|c|}
\hline \multicolumn{6}{|c|}{$\begin{array}{l}\text { Logging Engineers } \frac{R . V . \text { Cram }}{\text { Log depth reference at zero }(0.0)} \frac{\text { S. E. Kos }}{\text { depth is g }} \\
\text { Log }\end{array}$} \\
\hline Log Date & $\begin{array}{l}\text { Archive } \\
\text { file names }\end{array}$ & Log mode speed & $\begin{array}{l}\text { Depth } \\
\text { Top } \\
\end{array}$ & $\begin{array}{c}\text { interva } \\
\text { Base } \\
\end{array}$ & $\begin{array}{l}\text { (ft) } \\
\text { Incr }\end{array}$ \\
\hline \multirow[t]{2}{*}{ Dec 02,92} & H1N70\A291 & MSA $80 \mathrm{sec}$ RT & 0 & 97 & 0.5 \\
\hline & & Station $300 \mathrm{sec}$ & & & \\
\hline
\end{tabular}

Calibration and Analysis Information

RLS Calibration Date: Nov. 21, 1991

Calibration Report: WHC-SD-EN-TRP-001

Analyst Names: J.P. Kiesler

Analysis Date: Dec 3,1992

Analysis Notes: Elevated Total Gamma activity identifies Bentonite sea?. Radionuclides Identified: $\mathrm{C}_{0}-60$ 


\section{RLS Spectral Gamma-Ray Borehole Survey}

Project: $100-\mathrm{N}$

Borehole: $199-\mathrm{N}-70$

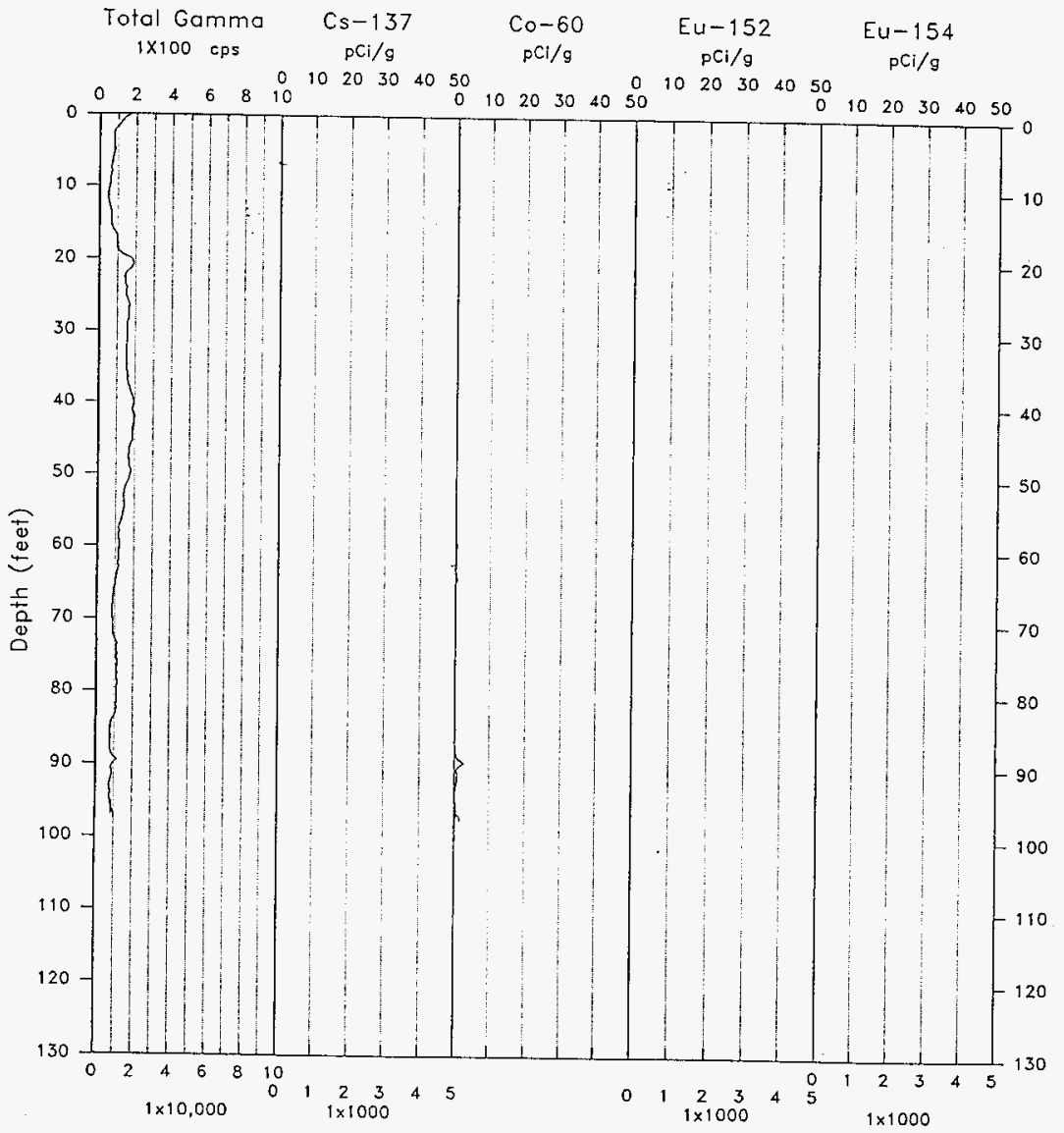

Log Date: Dec 2, 1992

Anal. Date: Dec 3, 1992 

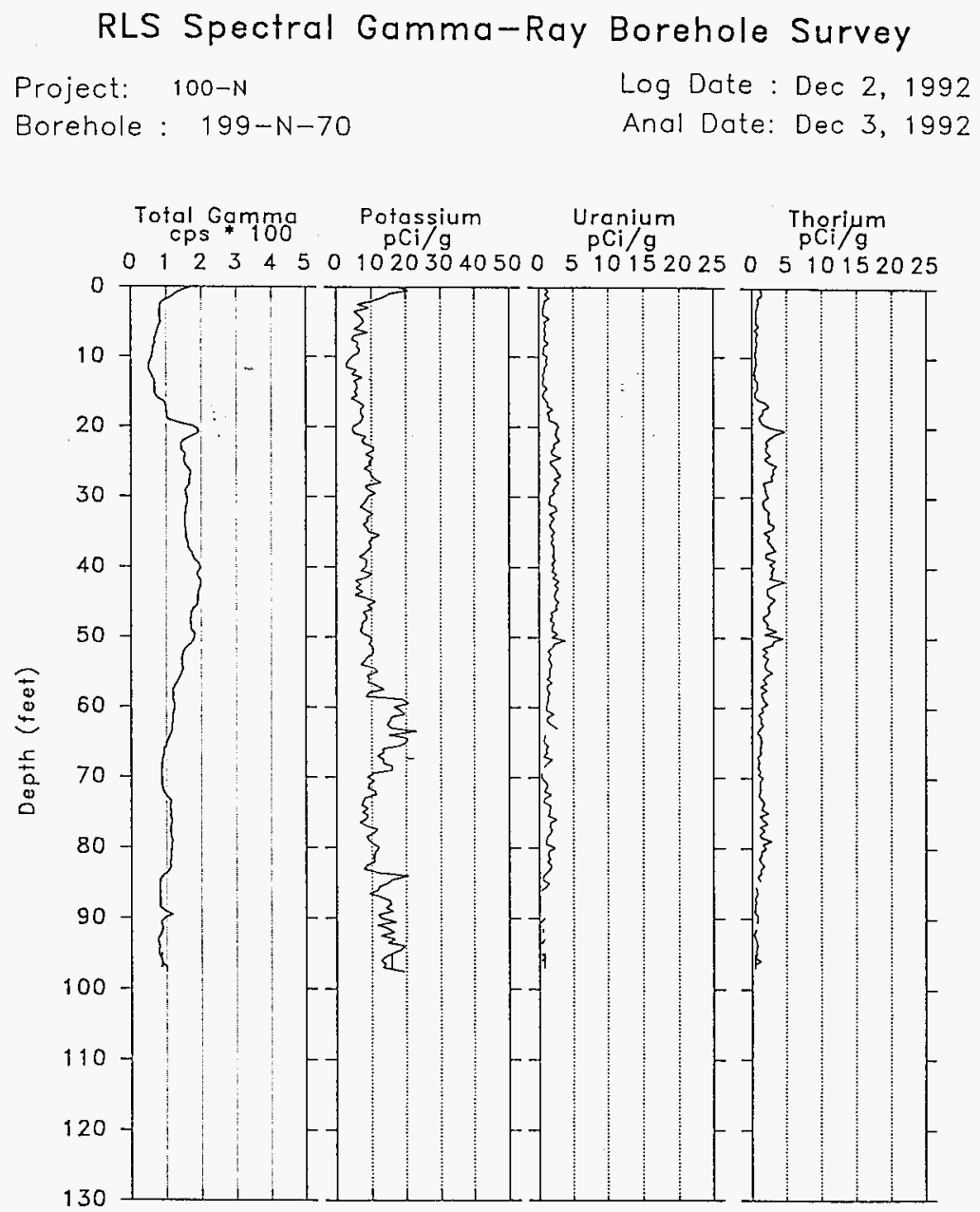


\section{WHC-SD-EN-TI-261, Rev. 0}

\section{RLS Borehole Survey Report}

Borehole: $\underline{199-\mathrm{N}-70}$

$\begin{array}{llll}\text { Casing } & \text { Depth: 103' } & \text { Size: 6" } & \text { Thickness: } 0.25 " \\ \text { Hater } & \text { Depth: } 59^{\prime \prime}, & & \\ \text { Survey } & \text { Depth: } 0-, 98^{\prime} & \text { Date: } 12 / 02 / 92 & \\ & \text { Station } 96^{\prime} & & \end{array}$

General Notes:

Survey of this borehole was based on a gross gamma survey containing elevated activity acquired earlier.

The lower zone at 89 feet, below the water depth of 59 feet, containing the maximum cobalt-60 activity is not the depth of the maximum total gamma activity.

The high total gamma activity from 17 to 57 feet correlates with an increase in natural uranium and thorium activity that is greater than normally present in Hanford environment. The presence of stainless steel casing may indicated bentonite sealing material between casing and formation. Bentonite contains natural uranium and thorium at higher concentrations than common to Hanford.

The plots for potassium, uranium and thorium show that the calculated potassium decay activities vary between about 3 and $23 \mathrm{pCi} / \mathrm{g}$ over the logged interval, and the uranium and thorium decay activities are less than $4 \mathrm{pCi} / \mathrm{g}$. The computed potassium decay activity varies inversely with the uranium and thorium activities, which is not common to the Hanford environment. The elevated uranium and thorium decay activity is believed to originate from the bentonite sealing material.

Man-made Radionuclides:

Cobalt $(\mathrm{C} 0-60)$ was discontinuous from 1 foot to 86 feet with calculated activities less than $1 \mathrm{pCi} / \mathrm{g}$. Cobalt was indentified continuously from 87 to 96 feet with a maximum detected activity of $2.7 \mathrm{pCi} / \mathrm{g}$ at $89.5 \mathrm{feet}$.

No Cesium (Cs-137) detected, template presented for uniformity of presentation only.

No Europium (Eu-152) detected, template presented for uniformity of presentation only.

No Europium (Eu-154) detected, template presented for uniformity of presentation only. 
Project: $100-N R-2$

\begin{tabular}{|lll|}
\hline $\begin{array}{l}\text { Borehole } \\
\text { Coordinates } \\
\text { Elevation }\end{array}$ & $199-\mathrm{N}-75$ & \\
\end{tabular}

Borehole Environment Information

\begin{tabular}{|c|c|c|c|}
\hline Borehole Fluid Depth 68.7 (Feet) from Zero (0.0) Depth Reference of Log \\
\hline $\begin{array}{c}\text { Casing Size } \\
\text { I.D. (inch) }\end{array}$ & $\begin{array}{c}\text { Casing Thickness } \\
\text { (inch) }\end{array}$ & $\begin{array}{c}\text { Top Depth } \\
\text { (feet) }\end{array}$ & $\begin{array}{c}\text { Base Depth } \\
\text { (feet) }\end{array}$ \\
\hline 12 & 0.40 & 0 & 20 \\
\hline 10 & 0.38 & 0 & 89.2 \\
\hline
\end{tabular}

RLS Passive Spectral Gamma Survey Information

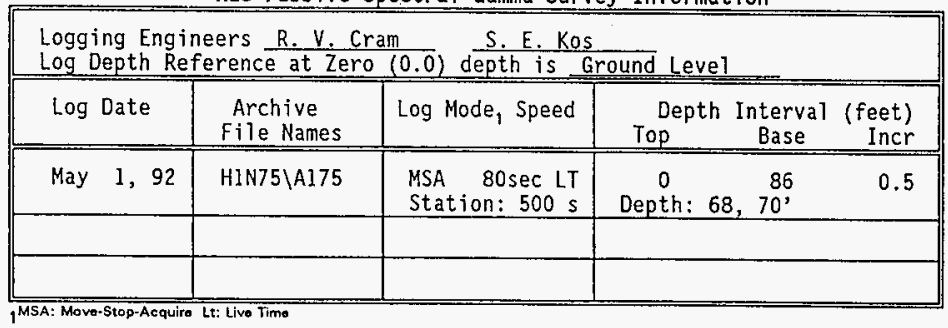

Calibration and Analys is Information

RLS Calibration Date: Nov 21, 1991

Calibration Report: WHC-SO-EN-TRP-001

Analyst Names: G.K. Jaeger R. K. Price.

Analysis Date: Aug 18, 1992

Analysis Notes: Very high background activity at surface to 1 foot Radionuclides identified: Co-60 $_{0}$ 


\section{WHC-SD-EN-TI-261, Rev. 0}

\section{RLS Spectral Gamma-Ray Borehole Survey \\ Project: $100-N R-2$ \\ Borehole: $199-N-75$ \\ Log Date : May 1, 1992 \\ Anal Date: Aug 18, 1992}

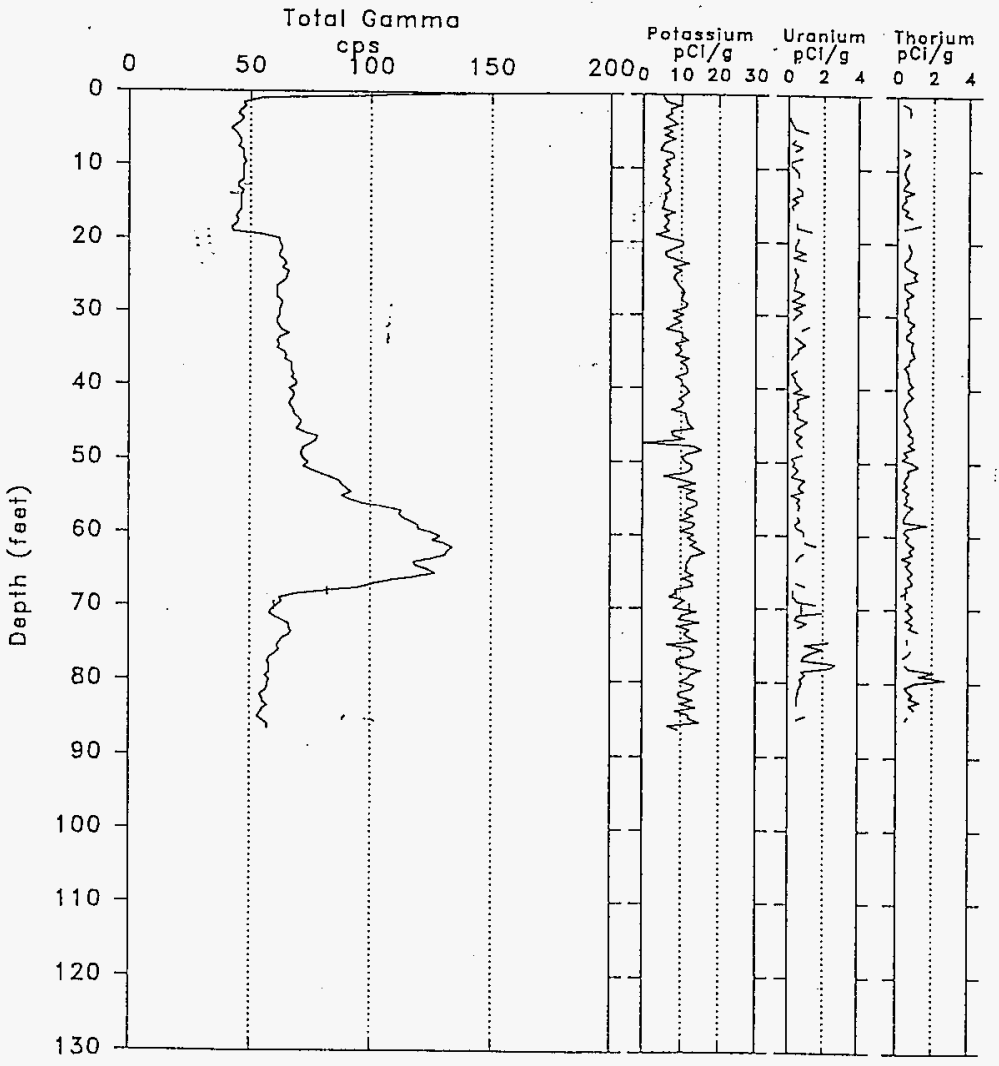


RLS Spectral Gamma-Ray Borehole Survey

Project: $\quad 100-N R-2$

Borehole: $199-\mathrm{N}-75$
Log Date: May 1, 1992

Analysis Date: Aug 18, 1992

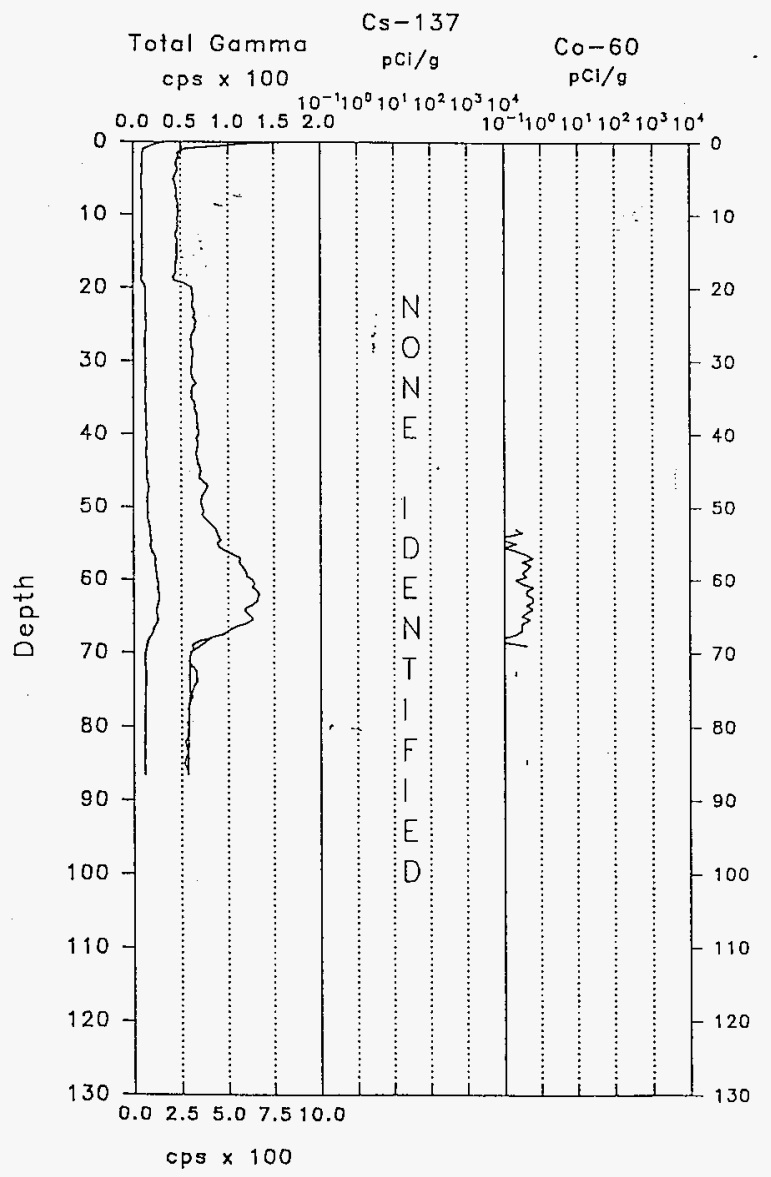




\section{WHC-SD-EN-TI-261, Rev. 0}

\section{RLS Borehole Survey Report}

$\underline{199-N-75}$

$\begin{array}{llll}\text { Casing } & \text { Depth: } 20^{\prime} & \text { Size: } 12^{\prime \prime} & \text { Thickness: } 0.40^{\prime \prime} \\ \text { Water } & \text { Depth: } 89^{\prime} & \text { Size: 10" } & \text { Thickness: } 0.38^{\prime \prime} \\ \text { Survey } & \text { Depth: } 68.7 & & \\ \text { Depth: } 0-86^{\prime} & \text { Mode: MSA 80sec LT } & \text { Date: } 5 / 01 / 92\end{array}$

General Notes:

Very high total gamma activity observed on the surface is identified in the borehole survey from 0 feet to 1 feet.

Man-made Radionuclidès:

No Cesium (Cs-137) was encountered in the borehole survey. The plot track is present only for uniformity of the displayed data.

Cobalt (Co-60) was encountered in the borehole from 52 feet to 85 feet. The cobalt decay activity detected is less than $1 \mathrm{pCi} / \mathrm{g}$.

No Europium-152 (Eu-152) was encountered in the borehole survey. The plot track is present only for uniformity of the displayed data.

No Europium-154 (Eu-154) was encountered in the borehole survey. The plot track is present only for uniformity of the displayed data. 
Westinghouse Hanford Company RLS Spectral Gamma-Ray Borehole Survey Log Header

Project: $100-\mathrm{N}$

$$
\begin{array}{ll}
\text { Borehole } \\
\text { Coordinates } \\
\text { Elevation }
\end{array} \frac{\frac{199-N-76}{150,622.12} \times \frac{571,560.08}{448.83} \mathrm{ft}}{\text { Bt }} \text { Brass Cap } \begin{gathered}
\text { (Lambert NAD'83) } \\
\text { (NGVD'29) }
\end{gathered}
$$

Borehole Environment Information

\begin{tabular}{|c|c|c|c|}
\hline \multicolumn{2}{|c|}{ Borehole fluid depth 67.1 (ft) from zero (0.0) depth reference of log } \\
\hline \hline $\begin{array}{c}\text { Casing size } \\
\text { (in.) }\end{array}$ & $\begin{array}{c}\text { Casing thickness } \\
\text { (in.) }\end{array}$ & $\begin{array}{c}\text { Top depth } \\
\text { (ft) }\end{array}$ & $\begin{array}{c}\text { Base depth } \\
\text { (ft) }\end{array}$ \\
\hline 4 & 0.28 & 0 & 82 \\
\hline & & & \\
\hline
\end{tabular}

RLS Passive Spectral Gamma Survey Information

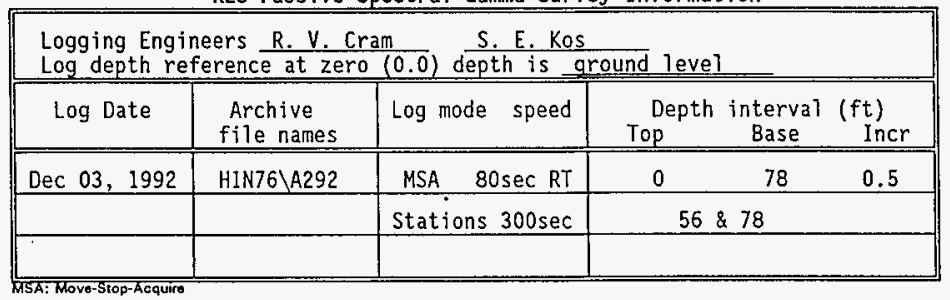

\section{Calibration and Analysis Information}

RLS Calibration Date: Nov. 21, 1991

Calibration Report: WHC-SD-EN-TRP-001

Analyst Names: J.P. Kiesler

Analysis Date: Jan 19, 1993

Analysis Notes:

Radionuclides Identified: $\mathrm{C}_{0}-60$ 


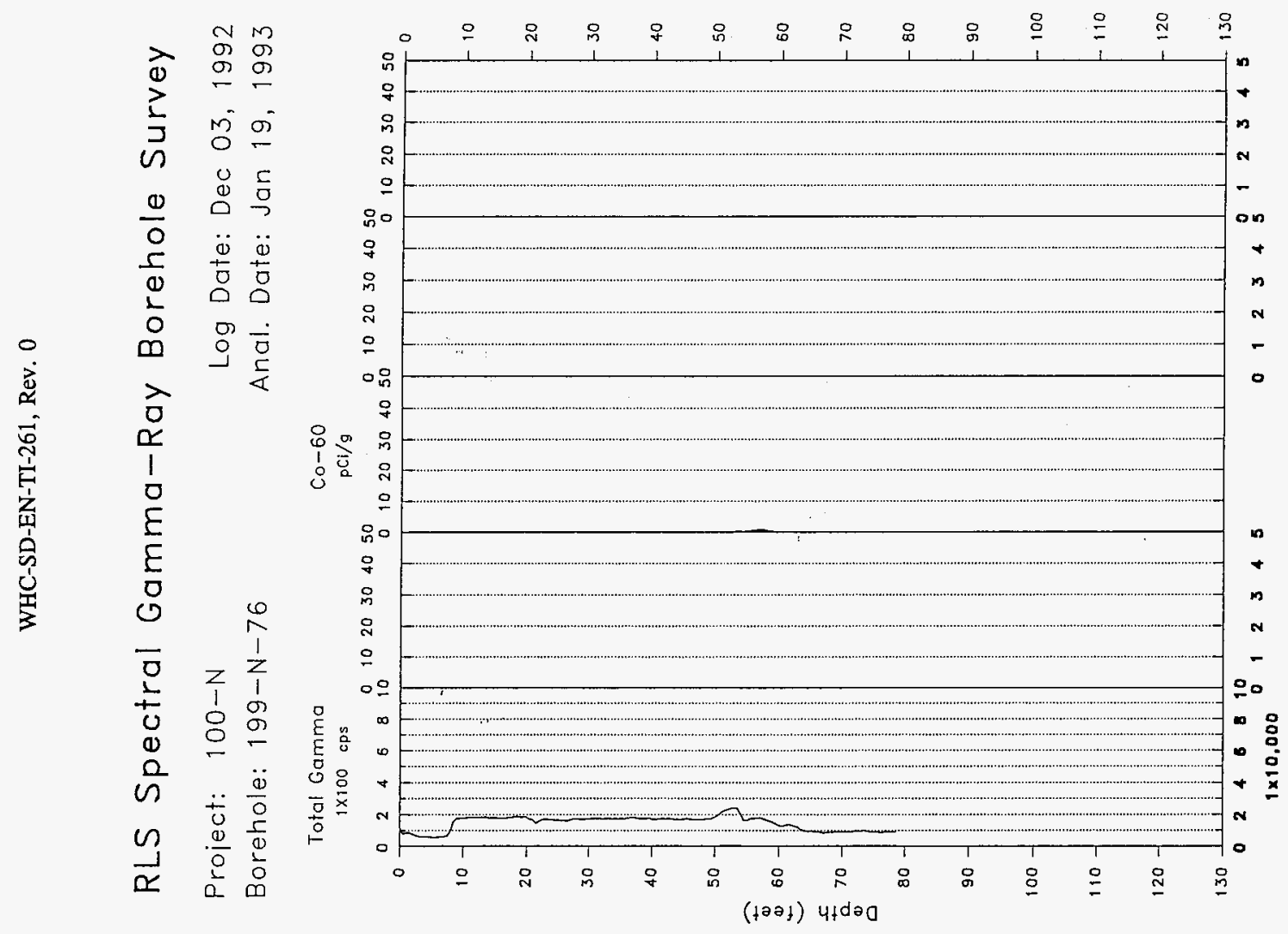




\begin{abstract}
RLS Spectral Gamma-Ray Borehole Survey
Project: $\quad 100-\mathrm{N}$

Borehole : 199-N-76

Log Date : Dec 03, 1992

Anal Date: Jan 19, 1993
\end{abstract}

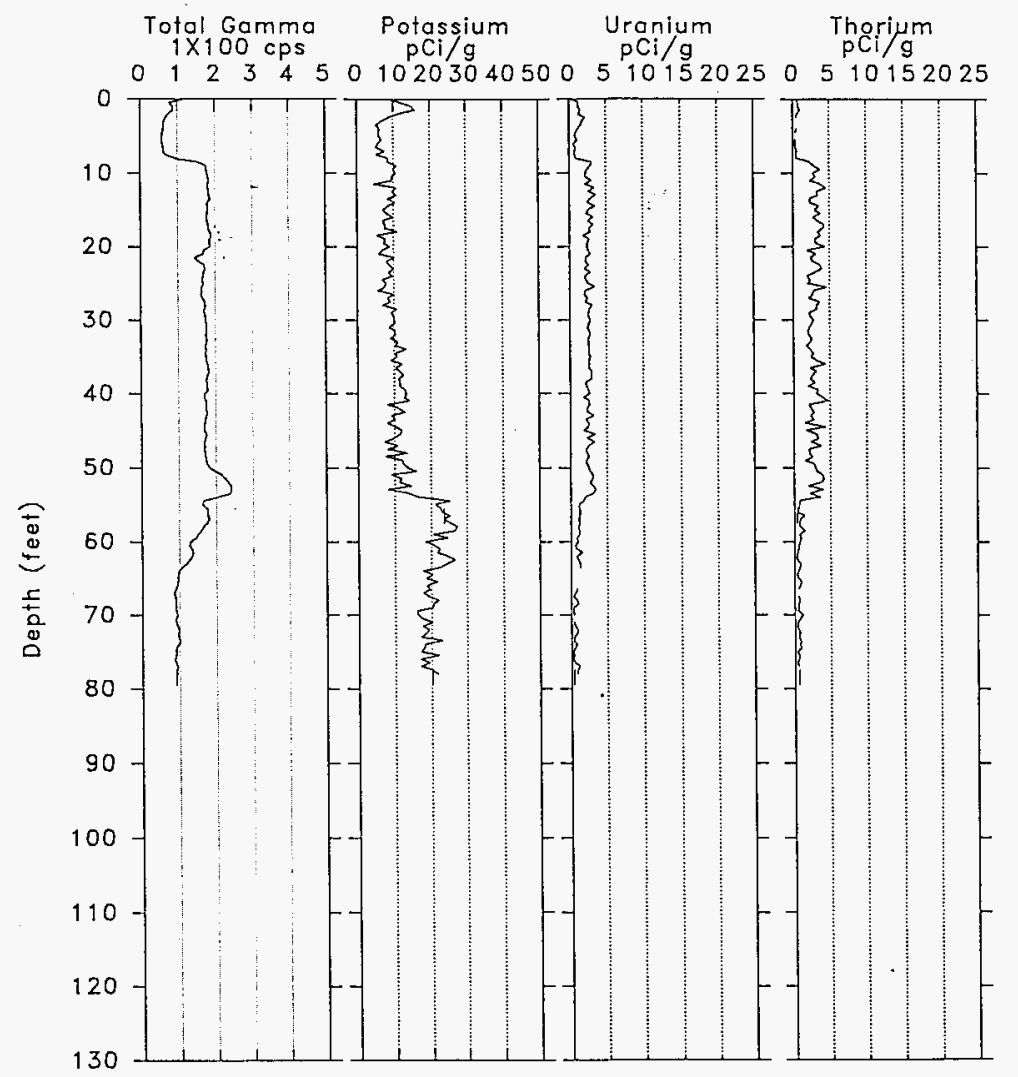


WHC-SD-EN-TI-261, Rev. 0

\section{RLS Borehole Survey Report}

Borehole: $199-\mathrm{N}-76$

$\begin{array}{llll}\text { Casing } & \text { Depth: } 82^{\prime} & \text { Size: } 4^{\prime \prime} & \text { Thickness: } 0.28^{\prime \prime} \\ \text { Water } & \text { Depth: } 67.1^{\prime} & & \\ \text { Survey } & \begin{array}{l}\text { Depth: } 0-78^{\prime} \\ \text { Stations: } 56 \& 78^{\prime}\end{array} & \text { Date: } 12 / 03 / 92 & \end{array}$

General Notes:

The plots for potassium, uranium and thorium show that the calculated potassium decay activities vary between about 5 and $27 \mathrm{pCi} / \mathrm{g}$ over the logged interval, and the uranium and thorium decay activities are less than $5 \mathrm{pCi} / \mathrm{g}$. The computed potassium decay activity varies inversely with the uranium and thorium activities, which is not common to the Hanford environment. The elevated uranium and thorium decay activity is believed to orginate from the bentonite sealing material.

The total gamma activity did not exceed $225 \mathrm{cps}$ in the borehole survey.

Man-made Radionuctides:

Cobalt-60 ( $\left.C_{0}-60\right)$ was identified in the borehole from 4 to 77 feet with the only continuous zone being 52 to 62 feet, with all calculated activities less than $1 \mathrm{pCi} / \mathrm{g}$. 


\section{WHC-SD-EN-TI-261, Rev. 0}

\section{APPENDIX B}

\section{THE RLS SYSTEM}

The Radionuclide Logging System (RLS) is a passive, high-resolution gamma-ray energy-spectrum logging system. The system utilizes a semi-conducting crystal of highpurity germanium (HPGe); the crystal is cooled during logging with liquid nitrogen, and an electrical potential is imposed across the crystal. Gamma-ray interaction with the crystal produces sharp electrical charge pulses with amplitudes in relation to the gamma-ray energy. Since each radionuclide emits a gamma ray with a distinct energy for that element, the charge pulse is recorded at a distinct point along the energy axis of the spectrum and thus permits the discrete identification of each radioelement present. (See Figure B-1.) With appropriate calibration, radioelement assay concentrations, as well as radionuclide identification, can be determined.

The logging cable equipped on the RLS was specifically designed for the system. It suspends the detector in the well, conducts power to the detector, receives electrical signals from the detector, and provides the conduit for venting the gaseous nitrogen from cooling the logging sonde. Errors in the depth-measuring system of the RLS are mainly related to cable stretch, cable and sheave wheel contact, and electronic encoding components. The recorded depth of the detector is estimated to be accurate to 98.5 percent, with a precision (repeatability) of 99 percent. Comparisons with drilling measurements, other logging equipment, and secondary measuring systems have verified the accuracy.

There are two configuration in which the logging sonde can be used. One is in the as-built state (standard) and the other (alternate) is with an external "shield" (gamma-rayabsorbing material) placed around it.

The standard logging configuration optimizes the counting system for detecting low decay activities of radioelements. The RLS has frequently detected man-made radioelement activities of $0.3 \mathrm{pCi} / \mathrm{g}$ for nuclides emitting gamma rays having energies greater than 500 $\mathrm{keV}$ and the number of gamma rays emitted per decay being at least one for each two decays (greater than 50 percent. The maximum decay activity the RLS has detected is about 10,000 $\mathrm{pCi} / \mathrm{g}$ in this standard configuration.

The alternate logging configuration at present employs a lead shield and changes the counting system to maximize the count rate. Configuring the counting system to maximize the count rate compromises its ability to detect radioelements at low decay activities (concentrations). The RLS has frequently detected man-made radioelement activities exceeding $33,000 \mathrm{pCi} / \mathrm{g}$ in this shielded configuration. The alternate logging configuration was not employed for the surveys included in this report because of the low count rates encountered. 
WHC-SD-EN-TI-261, Rev. 0

\section{LIMITATIONS TO THE RADIOELEMENT ANALYSES}

Borehole-environment correction factors have been determined for steel casing and water in the borehole. Correction factors for other borehole configurations have not been investigated. Borehole configurations for which no correction is available include: (1) grout between multiple casing strings, (2) formation seals containing bentonite, sand, or grout behind the casing, and (3) drilling mud remaining inside the borehole during logging. The calculated decay activity for man-made radionuclides will be underestimated for boreholes with these configurations.

Energy-dependent casing corrections have been established for steel casing thicknesses up to 0.40 inches. Corrections for casings of different materials and/or cumulative thicknesses greater than 0.40 inches have not been calculated and therefore cannot be used in the data reduction.

The calibration data were recorded with the detector centered in calibration zones that are uniform in density, water content, and gamma-ray source material. The dimensions of each zone are large enough that the detector always responded as though surrounded by a medium of infinite extent. Therefore, the use of the calibration results to calculate nuclide activity carries the assumption that the nuclides in the logged formation are also distributed in thick uniform layers. Gamma-ray sources are not normally distributed in the earth in thick uniform layers. Source inhomogeneities are reflected to some degree by the fluctuations in the amplitudes of the log traces. A factor called the "vertical spacial resolution" quantifies the correlation between (1) the amplitude of the log fluctuation and the depth interval over which it extends, and (2) the intensity of the corresponding gamma-ray source and the thickness of the zone in which the source is embedded. The vertical spatial resolution of the RLS HPGe logging system is scheduled for investigation.

Radionuclide decay activities are determined from the net area of the gamma-ray peaks, see Figure $x+1$. Radioelements such as strontium- 90 which do not emit a gamma ray when they decay will not be identified or quantified by the spectral analysis performed for this report. The decay of strontium-90 results in a high-energy beta particle that can excite surrounding elements to emit photon (gamma-ray) radiation that can be identified by the HPGe detector. This type of radiation is called "bremsstrahlung" radiation. A method to obtain estimates of the concentrations of strontium-90 is under consideration. 


\section{DISTRIBUTION SHEET}

\begin{tabular}{|c|c|c|c|c|c|}
\hline \multirow{2}{*}{$\begin{array}{l}\text { To } \\
\text { Distribution }\end{array}$} & \multirow{2}{*}{\multicolumn{3}{|c|}{$\begin{array}{l}\text { From } \\
\text { J. W. Fassett }\end{array}$}} & \multicolumn{2}{|l|}{ Page 1 of 1} \\
\hline & & & & \multicolumn{2}{|c|}{ Date $9 / 19 / 96$} \\
\hline \multicolumn{3}{|l|}{ Project Title/Work Order } & & \multicolumn{2}{|c|}{ EDT No. 610772} \\
\hline \multicolumn{3}{|c|}{$\begin{array}{l}\text { WHC-SD-EN-TI-261, Spectral Gamma-Ray Logging Report } \\
\text { for the } 100-\mathrm{N} \text { Area; Hanford, Washington }\end{array}$} & & \multicolumn{2}{|c|}{ ECN No. N/A } \\
\hline Name & MSIN & $\begin{array}{l}\text { Text } \\
\text { With All } \\
\text { Attach. }\end{array}$ & Text Only & $\begin{array}{l}\text { Attach./ } \\
\text { Appendix } \\
\text { Only }\end{array}$ & $\begin{array}{l}\text { EDT/ECN } \\
\text { Only }\end{array}$ \\
\hline $\begin{array}{l}\text { J. W. Fassett } \\
\text { J. I. Feaster } \\
\text { R. K. Price }\end{array}$ & $\begin{array}{l}H 6-06 \\
H 6-06 \\
N 1-55\end{array}$ & $\begin{array}{l}x \\
x \\
x\end{array}$ & & & \\
\hline $\begin{array}{l}\text { Central Fìles (2) } \\
\text { EDMC (2) }\end{array}$ & $\begin{array}{l}A 3-88 \\
H 6-08\end{array}$ & $\begin{array}{l}x \\
X\end{array}$ & & & \\
\hline
\end{tabular}

